\title{
Sargassum contamination and consequences for downstream uses: a review
}

\author{
Damien A. Devault ${ }^{1,2} \cdot$ Ronan Pierre $^{3} \cdot$ Hélène Marfaing ${ }^{3} \cdot$ Franck Dolique $^{2} \cdot$ Pascal-Jean Lopez $^{2}$
}

Received: 23 April 2020 / Revised and accepted: 9 September 2020

(C) Springer Nature B.V. 2020

\begin{abstract}
Sargassum spp. are brown algae present in the tropical and subtropical waters of the world's oceans. Benthic or pelagic, Sargassum spp. represent substantial amounts of biomass when drifted and massive beaching events also named "golden tides" are challenging for environmental and tourism managers. The Sargassum spp. biomass can be regarded as offering economic opportunities; however, micropollutant contamination counteracts this wealth. This review describes the contaminant uptake processes and the concentrations reached by various Sargassum species in regard to national and international norms for a variety of applications. Amongst the heavy metals, perhaps total arsenic content is the most salient: phytoaccumulation of arsenic is due to confusion in the phosphate transporter between arsenic and phosphate, thus leading Sargassum spp. to bioaccumulate arsenic actively. The levels reached could well give cause for concern across all potential applications, in particular for human and animal use. Similarly, there are concerns for the widespread applications or disposal of this biomass due to environmental impacts in the case of storage, landfill or composting. Organic micropollutants are too rarely studied to assert that there is global contamination. However, research studies focused on Sargassum spp. contamination confirmed environmental threats. But, without exhaustive analysis of routine algae contamination, the standard contamination level cannot be defined. Treating beach-cast or drifting Sargassum spp. as a waste is a Gordian knot, in that it involves investment, work and disposal surfaces, whilst not necessarily providing environmental and economic gains. However, Sargassum spp. are a raw material, a resource rich in a broad variety of constituents that could be processed for commercial applications or which could be used for production of energy. In this paper the authors review the diverse applications that can be considered and describe the relevant regulations and norms related to contaminants and effluents that need to be taken into account. However, if valorizing Sargassum spp. is currently valuable and promising, the quality of the raw material is a key starting point because fresh and sand-free algae are required: offshore gathering solutions need to be developed in order to limit Sargassum sp. contamination by pollutants from land so as to hinder algae decay.
\end{abstract}

Keywords Sargassum $\cdot$ Phaeophyceae $\cdot$ Valorization $\cdot$ Regulatory $\cdot$ Standards $\cdot$ Heavy metals $\cdot$ Arsenic $\cdot$ Extracts

\section{Introduction}

In the global context of environmental disruption, proliferative species can induce loss of habitat-forming species and may lead to significant changes in the structure and functioning of ecosystems and to species extinctions. Not only do

Damien A. Devault

damien.devault@univ-mayotte.fr

1 Département des Sciences et Technologies, Centre Universitaire de Formation et de Recherche de Mayotte, RN3, BP53, 97660 Dembeni, Mayotte, France

2 Unité Biologie des organismes et écosystèmes aquatiques (BOREA), Université des Antilles, MNHN, Sorbonne Université, Université de Caen Normandie, CNRS, IRD, Paris, France

3 CEVA, 83 Rue de Pen Lan, 22610 Pleubian, France macroalgae make up a large component of proliferative and/ or invasive species, but they also cause significant economic and environmental damage, over which there are only limited post-invasion control and management options (Ribera and Boudouresque 1995; Thresher 1999; Schaffelke et al. 2006; Anderson 2007; Schaffelke and Hewitt 2007; Leong et al. 2018). Amongst the macroalgae, Sargassum spp. have been used in Asia for decades and sometimes cultivated for their large spectrum of potential applications, including food, agriculture, medical applications or energy (Holdt and Kraan 2011; Milledge and Harvey 2016; Janarthanan and Senthil Kumar 2018; Latifah and Warganegara 2018; Taghavi et al. 2018, amongst many). Nonetheless, concerns persist because of the increasing reports of invasion in different regions worldwide.

Sargassum horneri and Sargassum muticum from Japanese and Korean shores have been shown to be invasive 
(Schaffelke et al. 2006; Valentine et al. 2007; Milledge and Harvey 2016; Belattmania et al. 2018a; Marks et al. 2018). Sargassum horneri is invasive in Taiwan (Sung et al. 2018), in Morocco (Belattmania et al. 2018a, b) and on Algeria's shores (Aouissi et al. 2018). Sargassum polycystum, from the South China Sea, became established in Oceania (Andréfouët et al. 2017) and S. muticum is reported on the Great Barrier Reef (Vye et al. 2018) and is broadly distributed across Europe (Harries et al. 2007; Josefsson and Jansson 2011). Moreover, global changes might also promote Sargassum sp. proliferation (Széchy et al. 2017; Graba-Landry et al. 2018; Olabarria et al. 2018).

The pelagic Sargassum fluitans and Sargassum natans were reported in the North Atlantic Ocean gyre since Christopher Columbus on his first trip (1492). Later on, another "Sargasso sea" was encountered in the South Atlantic by Dutch/Portuguese sailors but has been little documented in this early description (Lodewijcksz and Claesz 1609). Over the last decade, very large amounts of pelagic Sargassum spp. (expected to be millions of tonnes in a decade) have been beached on Caribbean, Gulf of Mexico and West African coasts, with increasing frequency and intensity. Besides their massive impacts on local ecosystems and economies and major health concerns, the valorization of the "golden tide seaweeds" could generate revenues contributing to clean-up operations, and develop new business opportunities worldwide for proliferating pelagic and benthic Sargassum spp. (PérezLópez et al. 2014; Van Hal et al. 2014; Milledge and Harvey 2016).

However, such opportunities have to be developed within the local regulatory framework relevant for each of these applications (i.e. biochemicals, feed, food, fertilizers, materials and energy). Whilst Sargassum sp. use is often not regulated per se, products developed from the biomass have to comply with regulations and norms of use. Whilst a review published on the use of various seaweeds in functional food by Holdt and Kraan (2011) remains relevant for Sargassum spp., a broader review across applications, taking into account the specificities of Sargassum spp., is still missing. This review focuses on members of the genus Sargassum and particularly the species $S$. fluitans and $S$. natans, in order to (i) access current knowledge on the content of potential pollutants, (ii) describe the proportion of valuable compounds, (iii) identify the current or putative applications and (iv) address compatibility with those regulations in force, in the countries affected.

\section{Pollutants of Sargassum spp.}

This section details the concentrations (in the context of pollutants) of possible micropollutants detected in Sargassum spp. and, when available, the sorption processes proposed for pollutant intake and/or accumulation (Pérez-Larrán et al. 2019).
Bioaccumulation of a pollutant involves both intake and adsorption to retain it within the biota. Severe bioaccumulation is observed when adsorption protects from degradation or metabolization. The following section identifies the remarkable intake processes and retention capacities of particular types of seaweed biomass.

\section{Organic micropollutants}

Organic micropollutants in Sargassum spp. are poorly documented. Organic micropollutants could be adsorbed by organisms because of their physical properties, for instance the surface/volume ratio (Torresi et al. 2017), or a 3D structure which can limit exchanges (Woignier et al. 2011), or due to the chemical composition of the algae, i.e. organic carbon content (Karickhoff et al. 1979).

Polycyclic aromatic hydrocarbons Polycyclic aromatic hydrocarbons (PAHs) are produced by human activities (fuel combustion within a closed system: the petrogenic PAHs) or due to combustion. Fires are due to human action or natural events (the pyrogenic PAHs): human ignition seems to predominate as a source of pyrogenic PAHs also (Marr et al. 1999; Larsen and Baker 2003; Stark et al. 2003). Whatever their source, both petrogenic and pyrogenic sources contribute to PAHs in seaweed samples (Neff et al. 2005; Morillo et al. 2008).

Adsorption of PAHs is driven by their chemical affinity for organic carbon and hydrophobic content: the $\mathrm{PAH}$ aromatic level is correlated with PAH hydrophobicity, and the latter has been shown to be correlated to adsorption strength (Madenjian et al. 1999). Since labile molecules, i.e. freely dissolved molecules, are more bioavailable than adsorbed ones, $\mathrm{PAH}$ aromaticity is also correlated with PAH persistence in the environment (Bertilsson and Widenfalk 2002; Tobiszewski and Namiesnik 2012).

Stout et al. (2018) reported that the offshore Deepwater Horizon MC 252 oil well blowout in the Gulf of Mexico and the subsequent oil spill were correlated to beachings of pelagic S. fluitans and S. natans. Data on Sargassum sp. contamination from the Gulf of Mexico showed that in an oil spill situation (so too a non-oil spill situation), the measured variability in concentrations was high (Table 1). Stout et al. (2018) revealed lower PAH contamination in $S$. natans and $S$. fluitans in offshore drifting thalli, as compared to onshore samples of the same species, despite a recent massive oil spill that had occurred a few months before their experiments. In another study, Seepersaud et al. (2018) studied PAHs in S. filipendula and S. vulgare from contrasted locations in Trinidad and Tobago, with oil extracted from Trinidad shallows and Tobago being considered as a relatively preserved island. They demonstrated that the biogeographical effect was dominant and dependent on human activity on the shore. 
Polychlorobiphenyls Polychlorobiphenyls (PCBs) have a hydrophobicity that increases with chlorination (Madenjian et al. 1999). James et al. (1987) found no lasting toxic effect on $S$. agardhianum and $S$. muticum using $2 \mu \mathrm{g} \mathrm{L}{ }^{-1} \mathrm{PCB}$ in seawater. Such concentration in seawater is high, considering the dilution effect due to the oceanic context. However, PCB contamination impacts Sargassum edibility. Indeed, it is known that hijiki, as $S$. fusiforme is named in Japan, where it is used for food, can be contaminated by PCB, and blood serum results for Japanese women indicate PCB contamination with hijiki consumption (Haraguchi et al. 2016).

Pesticides The sorption behaviour of pesticides is rather complex. Even if hydrophobicity broadly induces similar behaviour, especially for older formulations, more recent pesticides are partly designed to delude plant metabolism. In Martinique, French West Indies, studies have been carried out on the chlordecone threat. Chlordecone, a persistent organic pollutant used decades ago as insecticide by banana plantation, accumulated in $S$. natans and $S$. fluitans reaches equilibrium after $48 \mathrm{~h}$ of deployment on the surface of contaminated bays (Martial and Tirolien 2018; Devault et al. 2019, 2020). Projects on Sargassum sp. contamination by chlordecone in the French West Indies are currently under way.

Hydrazine Hydrazine effects were reported on $S$. agardhianum and $S$. muticum sporophytes, with mortality in 1 to 3 weeks (James et al. 1987). Mitochondria which appeared to be abnormal were also reported by North and James (1987) after a 4-day exposure to $0.25 \mu \mathrm{g} \mathrm{L}^{-1}$, suggesting that hydrazine might induce membrane injuries and arbitrary reorganization of cell content.

\section{Micropollutant sorption on to Sargassum sp. thalli}

As mentioned by Li et al. (2017a), the biosorption potential of Sargassum-derived products was extensively studied and well demonstrated for metals, but data are scarce for organic compounds. Amongst the few studies, most of them used non-living Sargassum sp. biomass and sometimes harsh conditions. For example, Rubín et al. (2006) studied the biosorption of phenolic compounds (phenol, 2-chlorophenol and 4-chlorophenol) on dried S. muticum at $60^{\circ} \mathrm{C}$, Chung et al. (2007) worked on phenanthrene sorption on dried $S$. hemiphyllum at $50{ }^{\circ} \mathrm{C}$, Li et al. (2017b) worked on tetracycline adsorption using carbon particles from seaweeds, Tabaraki and Nateghi (2016) worked on hydrazine sorption on dried and sieved S. ilicifolium and Liang et al. (2017) worked on the sorption of methylene blue by non-living S. hemiphyllum. The processes of sorption of hydrophobic organic compounds have mainly been studied from the point of view of their industrial removal, but the equivalent processes in natural conditions are essentially unknown. Meanwhile, the 
available results are very useful for understanding a number of sorption behaviours.

Rubin et al. (2006) indicated that the presence of $-\mathrm{OH},-\mathrm{COOH}$, $\mathrm{C}=\mathrm{O}$ and $\mathrm{C}-\mathrm{O}$ groups supported the adsorption of phenolic compounds: such groups activate the aromatic ring of monochlorophenols by chlorine, which favours the existence of donor-acceptor interactions between the phenolic compounds and the groups of the biosorbent surface.

Chung et al. (2007) worked on phenanthrene sorption, showing that it fits with a pseudo-second-order kinetic. Phenanthrene is a polycyclic aromatic hydrocarbon with a low hydrophobicity for this family of about 4.57. Optimal hydrazine sorption on $S$. ilicifolium was shown to have a $\mathrm{pH}$ of 7.5 , i.e. an in situ compatible $\mathrm{pH}$.

Methylene Blue is a specific pollutant from the dye industries. Liang et al. (2017) demonstrated that the Langmuir isotherm model provided the best correlation with experimental data on S. hemiphyllum, and that the monolayer biosorption capacity was $729.93 \mathrm{mg} \mathrm{g}^{-1}$ within $2 \mathrm{~h}$ but at acidic $\mathrm{pH}(\mathrm{pH}=$ 5) mainly due to surface hydroxyl, amine and carboxyl functional groups.

Li (2015) and Li et al. (2017a, b) noted tetracycline sorption onto S. hemiphyllum, fitted with the pseudo-first-order model (Langmuir) up to $278.4 \mathrm{mg} \mathrm{g}^{-1}$. Tetracycline is not hydrophobic $\left(\log K_{\mathrm{OW}}=-1.37\right)$ but interacts strongly with carbon particles: equilibrium is reached after a 2-h exposure. Solution $\mathrm{pH}$ and background ionic strength are important controlling parameters in the adsorption process as they affect the tetracycline speciation because, under acidic conditions, the amphoteric form promotes sorption. In such conditions, the surface binding sites of the layered carbon particles promote adsorption ability whilst outer-sphere association suppresses adsorption whilst increasing ionic strength.

Overall, organic micropollutants tend to show rapid and massive adsorption on modified Sargassum spp., driven by $\mathrm{pH}$, in accordance with adsorption at in situ $\mathrm{pH}$, at least for hydrophobic ones. In situ, Sargassum spp. could be expected to have a high capability of bioaccumulating organic compounds but probably not because of the seaweed organic contents (Gramatica et al. 2007). In general, the absence of strict correlation between $K_{\mathrm{OW}}$ and adsorption suggests that more studies are urgent to better understand the nature and the localization of sorption sites for seaweeds.

\section{Heavy metals}

The heavy metal content, as reported in selected references, in Sargassum spp. is summarized in Table 2.

In brief, metals mainly contaminate biota via cationic species. At the $\mathrm{pH}$ under consideration, heavy metal forms are summarized in Table 3. In the light of the many experiments performed to determine if Sargassum spp. could be an effective material for heavy metal removal, heavy metal speciation has to be examined at seawater $\mathrm{pH}$. For marine biota, it has been proposed that heavy metal speciation intrinsically drives bioaccumulation potential. At seawater $\mathrm{pH}$, even if $\mathrm{Cd}$ is almost fully available, $\mathrm{Zn}$ or $\mathrm{Cu}$ are not present in their most bioavailable species form, and the other species mentioned are only present in low-bioavailability forms. Bioavailability is therefore an important criterion for understanding bioaccumulation in Sargassum spp. and in parallel with biosorption, active transfer mechanisms need to be considered.

Indeed, metal sorption on Sargassum spp. is not homogeneous, as explained by Davis et al. (2000) and Schiewer and Wong (2000). Metal selectivity for sorption is based on their physico-chemical properties, i.e. conformation and ion strength, and on $\alpha$-L-guluronic acid content. Miao et al. (2014) observed the histological impact of heavy metal on $S$. pallidum ultrastructure in samples exposed to in situ contamination They showed that cell structures and walls are deformed and even broken, extra-numbered vacuoles appear, chloroplast grana are distorted or even disintegrated and stroma are disrupted and even leak (Miao et al. 2014). Losses of selective permeability can also induce alteration of metabolic pathways such as photosynthesis or oxidative mechanisms (Cabral 2003; Carreras and Pignata 2007; Zou et al. 2015). A domino-like effect for metals was proposed by Patra et al. (2004) with (1) weakening of cell membrane permeability, (2) reactions of sulphydryl groups with cations, (3) affinity for reacting with phosphate groups and active groups of ADP or ATP and (4) replacement of essential ions.

In Sargassum spp., heavy metal accumulation in cell walls and the role of alginate-rich (20-40\%) materials have been reported in many studies (Figueira et al. 1997; Kratochvil and Volesky 1998; Davis et al. 2000, 2003a, b, c; Sheng et al. 2004; Naja and Volesky 2006). Algal cell walls allow the free passage of molecules and ions in aqueous solutions (Hope and Walker 1975). Algal cell walls have metal-binding groups, which can explain divalent cation binding (Puranik et al. 1999; Khoo and Ting 2001; Chen et al. 2002, amongst many). In addition, the cell walls of brown algae contain metal-sequestering alginate and fucoidan (Figueira et al. 1999; Davis et al. 2000). Sargassum species present a twostage kinetic behaviour: very rapid initial sorption over a few minutes, followed by a long period of much slower uptake until equilibrium is reached after 1 to $3 \mathrm{~h}$. In general, about $90 \%$ of total metal ion sorption was achieved within the first $60 \mathrm{~min}$. Based on these results, in equilibrium experiments, $6 \mathrm{~h}$ was often deemed sufficient to establish equilibrium (Sheng et al. 2004).

Many experiments with different Sargassum species have used pseudo-second-order Freundlich, Langmuir and Dubinin-Radushkevich isotherms to fit sorption kinetics: see Fan et al. (2018a) for S. hemiphyllum, Foroutan et al. (2018) for S. oligocystum, Negm et al. (2018) for S. vulgare, Perez et al. (2018) for $S$. tenerrimum, Tukaram Bai and 


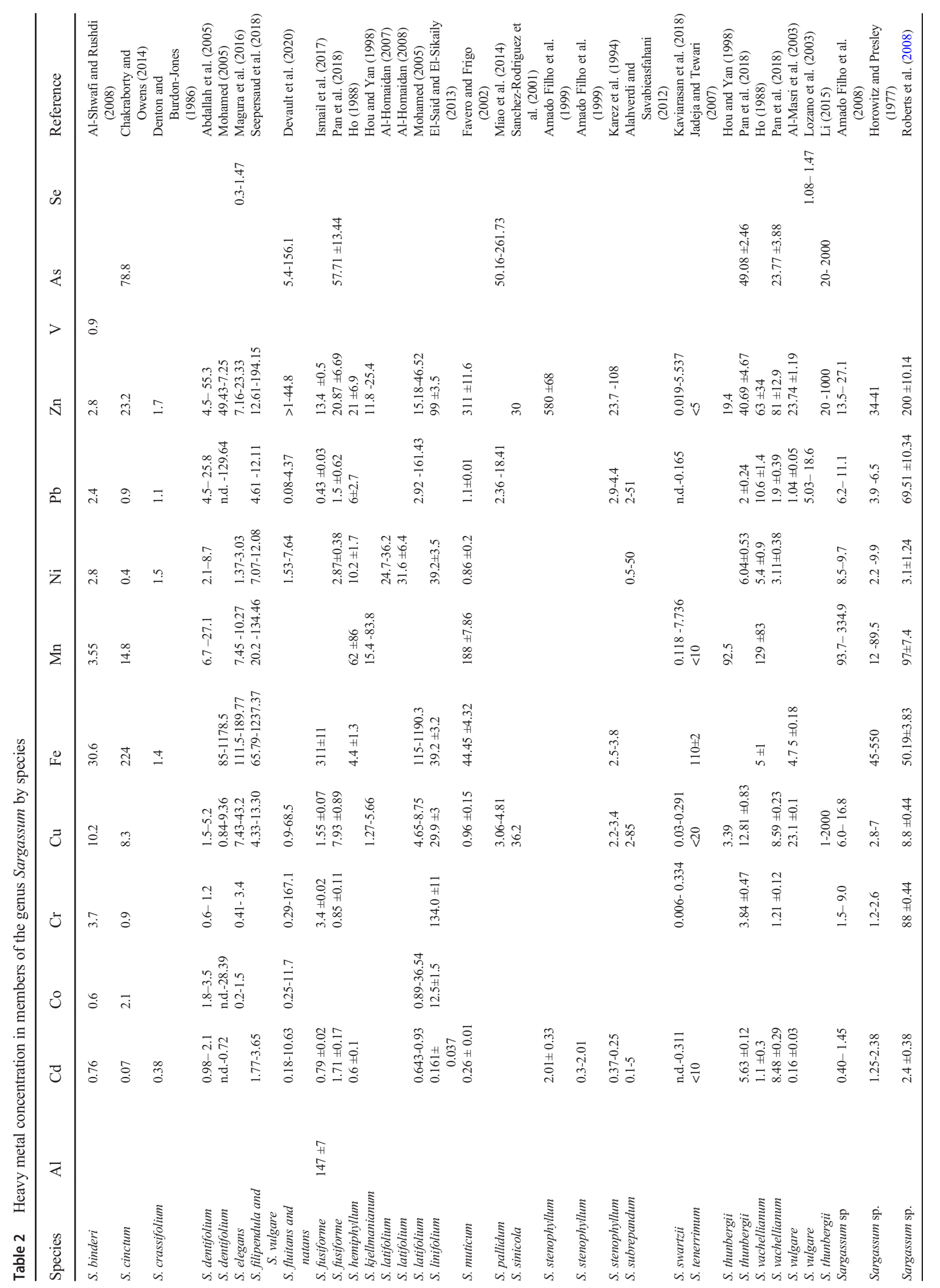


Venkateswarlu (2018) for S. crassifolium, Wang et al. (2018a) for S. horneri and Jalali et al. (2002), Lee and Volesky (1999) and Yang and Volesky (1999) for S. fluitans and S. natans. The Freundlich isotherm involves one layer of strong chemical-dominant adsorption pattern, the Langmuir isotherm involves two layers of weaker physical-dominant adsorption pattern and the Dubinin-Radushkevich isotherm involves physical adsorption. The two-stage behaviours could be explained by a combination of adsorption types due to the heterogeneity of the cell walls rather than the size variation of the biomass (Moino et al. 2020) and are in agreement with the second Fick's law concerning adsorption. Various functional groups might serve as sorption sites, differing with respect to the strength of the metal sorptive bond, as well as the rate of adsorption on these sites (Schiewer and Volesky 2000).

Nano-metal particles were shown to be scattered through the cytoplasm, and alginate is proposed to favour nanoparticle formation (Fig. 3), which, in turn, might induce wall damage. Miao et al. (2014) suggested that nano-metal particles could have a sequestration effect and may limit deleterious impacts. Such high-electron density deposits are rich in $\mathrm{C}, \mathrm{O}, \mathrm{Cl}, \mathrm{Cu}$, $\mathrm{Pb}$, As and $\mathrm{Hg}$. In contrast, phenol beads are 4-6 $\mu \mathrm{m}$ in diameter in normal conditions; in reported contaminated conditions, phenol masses are irregularly shaped and undersized $(<1 \mu \mathrm{m})$ (Miao et al. 2014).

The carboxyl groups of alginate play a major role in the complexation. Overall, it was shown that different species of algae and conspecific algae may present different adsorption capacities, but unfortunately, in situ experiments of heavy metal sorption on living Sargassum spp. have never been reported and are urgently needed for the benthic species $S$. fluitans and $S$. natans.

\section{Arsenic}

Arsenic concentrations found in Sargassum spp. are summarized in Table 4. Arsenic is a notorious and toxic metalloid, ubiquitous in the environment. Arsenate $(\mathrm{As}(\mathrm{V}))$ is the predominant inorganic form in aqueous and aerobic environments and is strongly adsorbed onto the surface of several aquatic organisms and oxidized minerals of $\mathrm{Fe}, \mathrm{Mn}$ and $\mathrm{Al}$ (Al Mamun et al. 2019). Arsenite (As(III)) is highly abundant under anoxic environments and is adsorbed weakly onto fewer minerals, making it a more mobile oxyanion (Smedley and Kinniburgh 2002). As(III) is expected to be 20 to 60 times more toxic than $\mathrm{As}(\mathrm{V})$ due to its tendency to react as a soft metal with thiols (Ferguson and Gavis 1972). Arsenic forms can change rapidly in the environment from one species to the other. However, if organic arsenic compounds are formed by As methylation, As species changes are no longer possible. Sargassum spp. are known for their massive arsenic content. Several studies on Sargassum spp. led to the proposal that $\mathrm{As}(\mathrm{V})$ is mistaken for phosphate, owing to physico-chemical similarities between $\mathrm{H}_{2} \mathrm{PO}^{4-}$ and $\mathrm{H}_{2} \mathrm{AsO}^{4-}$, and is transported 
Table 3 Heavy metal speciation at similar $\mathrm{pH}$

\begin{tabular}{lll}
\hline Metal & Species & References \\
\hline Lead $(\mathrm{Pb})$ & $\mathrm{Pb}\left(\mathrm{CO}_{3}\right)_{2}[100 \%]$ & Powell et al. (2009) \\
Zinc $(\mathrm{Zn})$ & $\mathrm{Zn}^{2+}[55 \%] ; \mathrm{ZnOH}^{+}[35 \%] ; \mathrm{Zn}(\mathrm{OH})_{2}[10 \%]$ & Sjöberg et al. (2013) \\
Chromium $(\mathrm{Cr})$ & $\mathrm{Cr}(\mathrm{OH})_{2}{ }^{+}[45 \%] ; \mathrm{Cr}(\mathrm{OH})_{3}[45 \%]$ & Dos Santos et al. (2011) \\
Cadmium $(\mathrm{Cd})$ & $\mathrm{Cd}^{2+}[97 \%] ; \mathrm{Cd}(\mathrm{OH})^{+}[3 \%]$ & Powell et al. (2011) \\
Copper $(\mathrm{Cu})$ & $\mathrm{CuOH}^{+}[60 \%] ; \mathrm{Cu}^{2+}[17.5 \%] ; \mathrm{Cu}(\mathrm{OH})_{2}(\mathrm{aq})[17.5 \%] ; \mathrm{CuSO}_{4}{ }^{-}[5 \%]$ & Smith et al. (2015) \\
Arsenic $(\mathrm{As})$ & $\mathrm{As}(\mathrm{III}): \mathrm{H}_{2} \mathrm{AsO}{ }_{3}^{-}[90 \%] ; \mathrm{H}_{3} \mathrm{AsO}[10 \%]-\mathrm{As}(\mathrm{V}): \mathrm{HAsO}_{4}{ }^{2-}[95 \%] ; \mathrm{HAsO}_{4}{ }^{-}[5 \%]$ & Sø 2011 \\
Nickel $(\mathrm{Ni})$ & $\mathrm{NiCO}{ }_{3}(\mathrm{aq})[3 \%] ; \mathrm{Ni}\left(\mathrm{CO}_{3}\right)_{2}{ }^{2-}[97 \%]$ & Pyle et al. (2002) \\
Mercury $(\mathrm{Hg})$ & $\mathrm{Hg}(\mathrm{III}): \mathrm{Hg}(\mathrm{OH})_{2}(\mathrm{aq})[100 \%]$ & Powell et al. (2005) \\
\hline
\end{tabular}

by phosphate transporters (Taylor and Jackson 2016). The competition between $\mathrm{P}$ and $\mathrm{As}(\mathrm{V})$ for absorption sites may induce a drop in the concentration of $\mathrm{P}$ within algal tissues and an increase in $\mathrm{As}(\mathrm{V})$ concentrations. In contrast, Benson (1984) hypothesized that Sargassum spp. present higher levels of $\mathrm{As}(\mathrm{V})$ when a lower phosphate level is available. On the other hand, the interference of As(III) over uptake might not be inhibited by variations in uptake pathways: $\mathrm{P}$ absorption was found to be independent in the presence of As(III). As(III) is thought to be transported through an aquaglyceroporin channel as neutral $\mathrm{As}(\mathrm{OH})_{3}$ (Meharg 2004). To explain low phosphate accumulation in biota, Benson et al. (1988) hypothesized that this was because arsenate is much less stable than phosphate, and biological reducing agents can reduce arsenate, whilst reduction of phosphate is not possible.

Whilst there are proposals regarding the mechanisms involved, arsenic retention in Sargassum spp. is not fully understood. Studies have been conducted to understand the fate of arsenic in algae, including Sargassum spp. In marine environments, inorganic arsenic present in seawater was shown to be transformed into organo-arsenic species, mainly arsenoribosides in algae and arsenobetaine in animals (Maher et al. 2009). In macroalgae species, degradation of such less toxic forms leads to thio-arsenoribosides, dimethylarsinoylethanol (DMAE), dimethylarsenate (DMA) and methylarsenate (MA). As(V) can be recycled in seawater due to microbial communities (Duncan et al. 2014), in contrast to the fate of arsenobetaine, which is known to bioaccumulate in biota (Duncan et al. 2015).

In studies of arsenate metabolism, it has been proposed that a primary reaction with adenosine triphosphate (ATP) yields the unstable phosphoric arsenic anhydride (APAs), whose brief lifetime restricts its metabolic capabilities. Benson et al. (1988) interpreted the latter as a reduction of this fugacious intermediate by adenylyl sulphate reductase, or possibly a more specific enzyme. Reductions of arsenate and methyl arsenate to arsenous acid or methylarsenous acid (arsine oxide or methylarsine oxide) proceed in the presence of chloroplasts in light (Hill reaction) (Benson et al. 1988). The arsenous acids or their dehydrated forms, the arsine oxides, seem to react easily with accessible -SH groups to form arsenous thioesters. The nature of the thiol determines the stability and exchange rates of such esters. Monothioesters of arsenous acid seem to be able to further react and, with a second thiol, form arsenous dithiol esters which are also exchangeable with free thiols. Dithiols with proper spatial relationships, such as lipoic acid, 2,3-dimercaptopropan-1-o1 (BAL) or dithiothreitol, form much more stable and difficulty-exchangeable arsenous dithiol esters. Thus, dithiothreitol removes bound arsenous acids from monothiol ester linkages on algal proteins to produce a soluble cyclic arsenous dithiol ester. This metabolic pathway was proposed to predominate in Sargassum spp. but considered as marginal in other algae (Benson et al. 1988).

As indicated by García-Sartal (2012), brown seaweeds contain higher amounts of total arsenic than other seaweed classes (Dawczynski et al. 2007). Arsenosugars, i.e. the main arsenic compounds found in seaweed, are due to complex biosynthesis pathways which are still to be explored. As detailed elsewhere, arsenate absorption metabolism by seaweeds is similar to that reported for phosphate. Arsenosugars could

Table 4 Arsenic concentration diversity in Sargassum by species

\begin{tabular}{lll}
\hline Reference & Species & Arsenic $\left(\mu \mathrm{g} \mathrm{g}^{-1}\right)$ \\
\hline Edmonds et al. (2000) & Sargassum lacerifolium & $2.0-40$ \\
Han et al. (2009) & Sargassum fusiforme & $65.3-84.1$ \\
Pichler et al. (2006) & Sargassum horneri & $114.3 \pm 27$ \\
Leal-Acosta (2013) & Sargassum sinicola & $62-640$ \\
Leal-Acosta (2013) & Sargassum sinicola & $32-80$ \\
Maher 1983 & Sargassum fallax & $64-123$ \\
Ruiz Chancho (2010) & Sargassum ramifolium & $11-66.3$ \\
Ruiz Chancho (2010) & Sargassum vulgare & $16.1-58.8$ \\
Ruiz Chancho (2010) & Sargassum fulvellum & $115 \pm 9$ \\
Rose et al. (2007) & Sargassum fusiforme & $18-124$ \\
& Sargassum fusiforme & $37-146$ \\
\hline
\end{tabular}


be the end products of a detoxifying mechanism, due to reduction into DMA(V) with the $S$-adenosylmethionine acting as a methyl group donor (Craig 2003), then reduced glycosylation to DMA(III) due to the adenosyl group of $S$ adenosylmethionine and a glycosylation, leading to dimethylarsinoylribosides (Craig 2003; Murray et al. 2003) (Fig. 2). Arsenosugarphospholipids could be the precursor of arsenosugars in the event of excess regulation of arsenosugarphospholipids in phosphate-rich environments (Raber et al. 2000). Cyclic arsenous dithiol esters in various species of Sargassum are soluble. In the event of leaching, arsenic forms will be mobile, in contrast to other cell wallbound metals, as Ender et al. (2019) suggest for Laminaria. However, is such a soluble form adequate for storage?

$\mathrm{As}(\mathrm{V})$ adsorbed on $\mathrm{Fe}$ has consequences because iron plaques are naturally agglomerated in intercellular spaces (Fig. 1). They are non-specifically adsorbed and tightly complexed or scavenged on plaque surfaces in the presence of strong natural chelates that can sequester a number of nutrients and trace elements including arsenic (Rue and Bruland 1995; David et al. 1999; Khan et al. 2016). However, little is known about the accumulation potential of As species in terms of $\mathrm{Fe}$ plaque. Al Mamun et al. (2019), who studied this phenomenon, proposed that the $\mathrm{P}$ and $\mathrm{Fe}$ in the medium significantly inhibited the intracellular uptake of $\mathrm{As}(\mathrm{V})$, leading to heterogeneity in As accumulation inside/outside of tissues. Such adsorption could limit arsenic leaching but in an unknown range.

\section{Sargassum spp. composition and compounds of interest for valorization}

\section{Sargassum composition}

When looking at the potential use of various members of the genus Sargassum in various applications, understanding their biochemical composition is essential (Fig. 2). However, data relative to their composition are usually only partial. Whilst many authors have analysed specific components, there are relatively few complete studies on the global composition of Sargassum samples. Moreover, the broad diversity of the analytical methods used, especially for fibres and polysaccharides, or contents calculated by difference, may introduce biases and thus limit the possibilities for obtaining comparative information on various species. In addition, Sargassum spp. composition is highly dependent on various factors such as geographical origin of the seaweed, season or even the plant part analysed (Prince and Daly 1981; Bird et al. 1990). Consequently, intraspecific variation measured is high, and no interspecific variations can be assessed. Tables 5 and 6 summarize the best overview we could construct on the biochemical composition of pelagic and benthic Sargassum species.

\section{Specific compounds of interest}

\section{Minerals}

Seaweeds are known for their high mineral content, usually containing $20-40 \%$ of ash, and Sargassum spp. are no exception (Tables 5 and 6). Whilst the anionic fraction is usually composed mostly of chloride (50\%) as well as sulphates and carbonates (Hou and Yan 1998), other compounds within the seaweed, including cell wall anionic and sulphated polysaccharides, are known to interact with cations strongly and selectively. These interactions combined with physiological and environmental factors lead to a great diversity of minerals and trace elements (Hou and Yan 1998; Circuncisão et al. 2018). Whilst this may lead to accumulation of undesirable minerals and heavy metals as exemplified above, it is also the source of many nutrients of interest for food and feed applications: sodium/potassium with an interesting $\mathrm{Na} / \mathrm{K}$ ratio (Circuncisão et al. 2018), calcium, magnesium, sulphur, iron, iodine, copper, zinc or selenium.

Amongst those minerals, iodine can be present at particularly high levels, especially in brown seaweeds. Mairh et al. (1989) describe concentrations ranging from 500 to $1500 \mathrm{ppm}$ iodine in S. tenerrimum, S. johnstonii and S. filipendula, whilst Hou and Yan (1998) measure values ranging from $100 \mathrm{ppm}$ (S. thunbergii) to $6000 \mathrm{ppm}$ (S. vachellianum and $S$. henslowianum). These latter values are amongst the highest ever measured values for brown seaweed. Whilst these high values may create concerns with recommended limits for humans (see "Regulatory constraints") or feed applications (see "Regulatory constraints"), brown seaweed has been used for 2000 years in traditional Chinese medicine, especially for thyroid diseases and goitre (Liu et al. 2012) and may be relevant for specific populations such as pregnant women and young children (Andersson et al. 2012). This high iodine content may also play a role as an anti-bacterial agent and present benefits for health applications or to improve seaweed preservation. Lastly, this high mineral content, especially potassium, may be of agronomic interest, even if the sodium chloride content can limit direct uses in agricultural applications (see "Direct spreading").

\section{Carbohydrates}

Whilst total carbohydrate content in seaweeds can be relatively high, carbohydrates contain mostly polysaccharides. The main carbohydrate families found in Sargassum spp. are alginates, fucose-containing sulphated polysaccharides (usually described as fucoidans), laminarin and mannitol, as well as cellulose, which, in most studies, is not quantified. 
Fig. 1 Conceptual model for the extracellular and intracellular accumulation of arsenic from arsenic treatments modified with iron and phosphate (Al Mamun et al. 2019)

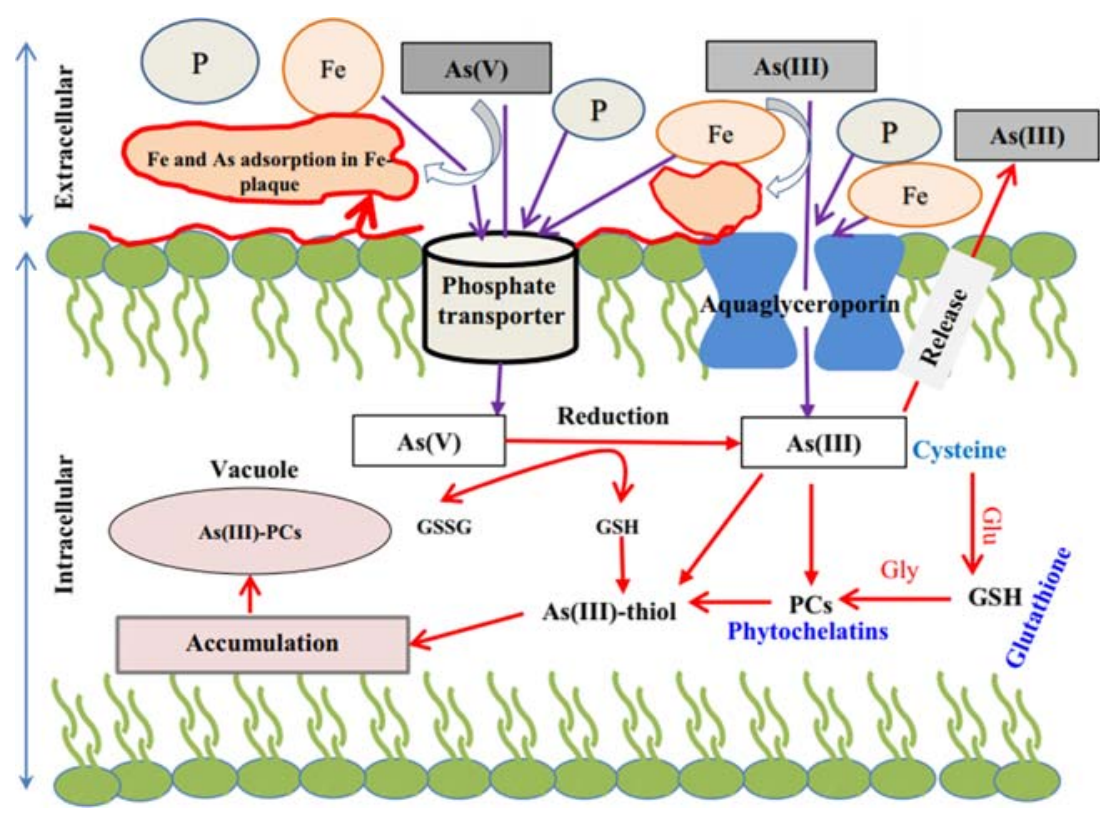

Except for some storage polysaccharides, the digestibility of seaweed polysaccharides by humans and animal species is generally low and they are usually considered as dietary fibres. Nevertheless, their specific structures and solubility characteristics can impair measurements with some traditional fibre methods developed for feed uses of land-based plants, which may not be relevant for seaweed, even if they are sometimes applied (e.g. neutral/acid detergent fibres). Moreover, total carbohydrates in food and feed applications are often calculated by difference (100 $-($ proteins + lipids + minerals + fibres $))$. With uncertainties regarding fibre determination, as well as additional categories which can represent a significant part of the seaweed (e.g. 5-15\% polyphenols in some brown algae), this formula may also turn out to be very approximate. Knowing this, the contents reported for fibres, digestible carbohydrates and total carbohydrates should be considered with care, as illustrated by the variations in fibres and total carbohydrates compiled in Tables 5 and 6 .

Alginates Alginates are the main constituents of the cell walls of brown seaweeds (Bird et al. 1990; Davis et al. 2003c). They usually represent $10-40 \%$ of algal dry weight, but their content depends not only on species, season and climate but also on local conditions (e.g. wave intensity). The alginate content in S. natans and S. fluitans is within 15-25\% (Table 5), but values ranging from 3 to $40 \%$ have been reported (Bird et al. 1990; Zubia et al. 2008). The highest values should be taken with care as some authors express the alginate content after algae demineralization of the algal tissues (Davis et al. 2004); nevertheless, Bird et al. (1990) measured a content of $28 \%$ for S. fluitans.
Alginates, mostly extracted from kelp species (Laminariales) but also sometimes from Fucales (Ascophyllum and Durvillaea spp.), are processed at industrial scale for the production of texturants (Fig. 3). Beyond extraction yield, their molecular weight and chemical composition (balance and distribution of guluronic and mannuronic acids) are a key for their properties and market value. Alginates from Sargassum spp. are usually considered to be of poor quality and more difficult to extract than alginates from kelp species, and production yields are low compared to other species used industrially, for which alginate content is usually above $30-40 \%$. Consequently, their processing remains very limited and does not stand out in global reports (Porse and Rudolph 2017). Nevertheless, only a limited number of studies on Sargassum spp. alginates are available, and some elements tend to demonstrate a high variability in composition depending on species, sites and harvesting period (Berteau and Mulloy 2003; Davis et al., 2003a, 2004; Torres et al. 2007; Bertagnolli et al. 2014; Mohammed et al. 2020).

Fucose-containing sulphated polysaccharides Fucose-containing sulphated polysaccharides (FCSPs), often referred to as fucoidans, are the second main constituents of brown seaweed cell walls (after alginates), which are further reinforced by cellulose microfibrils. They are characteristic of brown algae but present a very broad diversity of structures. Whilst true fucans or fucoidans, presenting a fucose backbone, can be found in Laminariales and some species of Fucales (Fucus spp., Himanthalia elongata), numerous FCSPs contain only a fraction of fucose and numerous other monosaccharides and uronic acids (glucose, 
Fig. 2 From Edmonds (2000): compounds $\mathbf{1 a}$ and $\mathbf{1 b}$ from Sargassum, however, contain a substituent on arsenic that seems unrelated to any that could be provided by $S$ -

adenosylmethionine. This is also true of compound $\mathbf{5}$ isolated from Tridacna kidney (Francesconi et al. 1992) which has been identified by NMR spectroscopy and its structure confirmed by synthesis (Eichenberger 1993). So, the origin of these substituents can now be considered.

Compounds $\mathbf{1 a}$ and $\mathbf{1 b}$ are similar to the polar portion of lipid $\mathbf{6}$, a significant membrane component of several species of algae (Sato 1988), except that whilst 6 has the trimethylammonio group, 1a and 1b have an arsenic group that carries two methyl groups and a 5'-deoxyribose-5'-yl group as substituents. This latter group is related to the major dimethylarsinoylribose derivative 2a of Sargassum lacerifolium. The similarities between compounds $\mathbf{1 a}$ and $\mathbf{1 b}$ of S. lacerifolium. The similarities between compounds $\mathbf{1 a}$ and $\mathbf{1 b}$ and $\mathbf{6}$ suggest that they might originate in parallel biosynthetic processes<smiles>CC[C@H](O)COS(=O)(=O)[O-]</smiles>

galactose, mannose, xylose, glucuronic acid), with various patterns of branching and substitution (sulphates, acetates). Sargassum FCSPs fall in the latter case, and the most recent publications describe a backbone essentially composed of sulphated mannose, galactose and glucuronic acid, with sulphated fucose mostly present in side chains (Berteau and Mulloy 2003; Ale and Meyer 2013; Deniaud-Bouët et al. 2017).

These FCSPs are credited with a large part of the health benefits attributed to Sargassum spp. in traditional Chinese medicine (Liu et al. 2012). Extensive work has been performed to demonstrate their anti-viral, anti-cancer, antithrombotic or anti-inflammatory properties, as well as their potential uses in cosmetic applications (Berteau and Mulloy 2003; Holdt and Kraan 2011; Wijesekara et al. 2011; Liu et al. 2012; Deniaud-Bouët et al. 2017). It should also be noted that many publications are focused on the testing of FCSP extracts, but relatively few actually provide detailed information on their structure, or even their content in the seaweed, which limits perspectives for industrial uses and understanding of structure-function relationships. Analyses performed over recent years on various pelagic and benthic Sargassum spp. (Li et al. 2018a; CEVA, unpub.) show FCSP contents in the 3$12 \%$ range.

Laminarin Laminarin is a storage polysaccharide exclusively observed in brown seaweed species, including Sargassum spp. (Davis et al. 2003b; Holdt and Kraan 2011; Kadam et al. 2015). It is a branched (soluble) or unbranched (insoluble) glucose polysaccharide, mostly in the form of $\beta$-(1,3)-glucan, with some 6-O branching in the main chain and some $\beta$-(1,6)-intrachain links, as well as a potential terminal mannitol group (Kadam et al. 2015). 


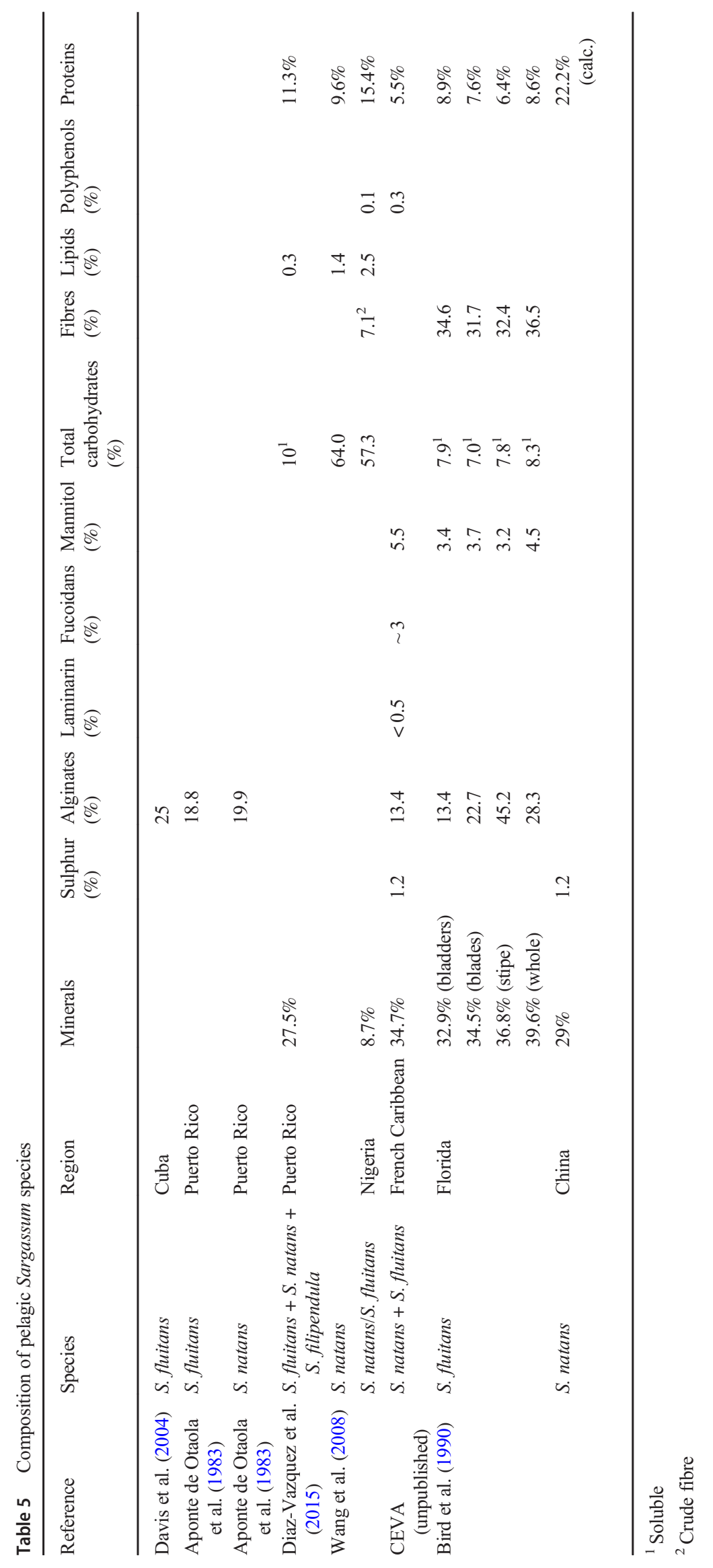




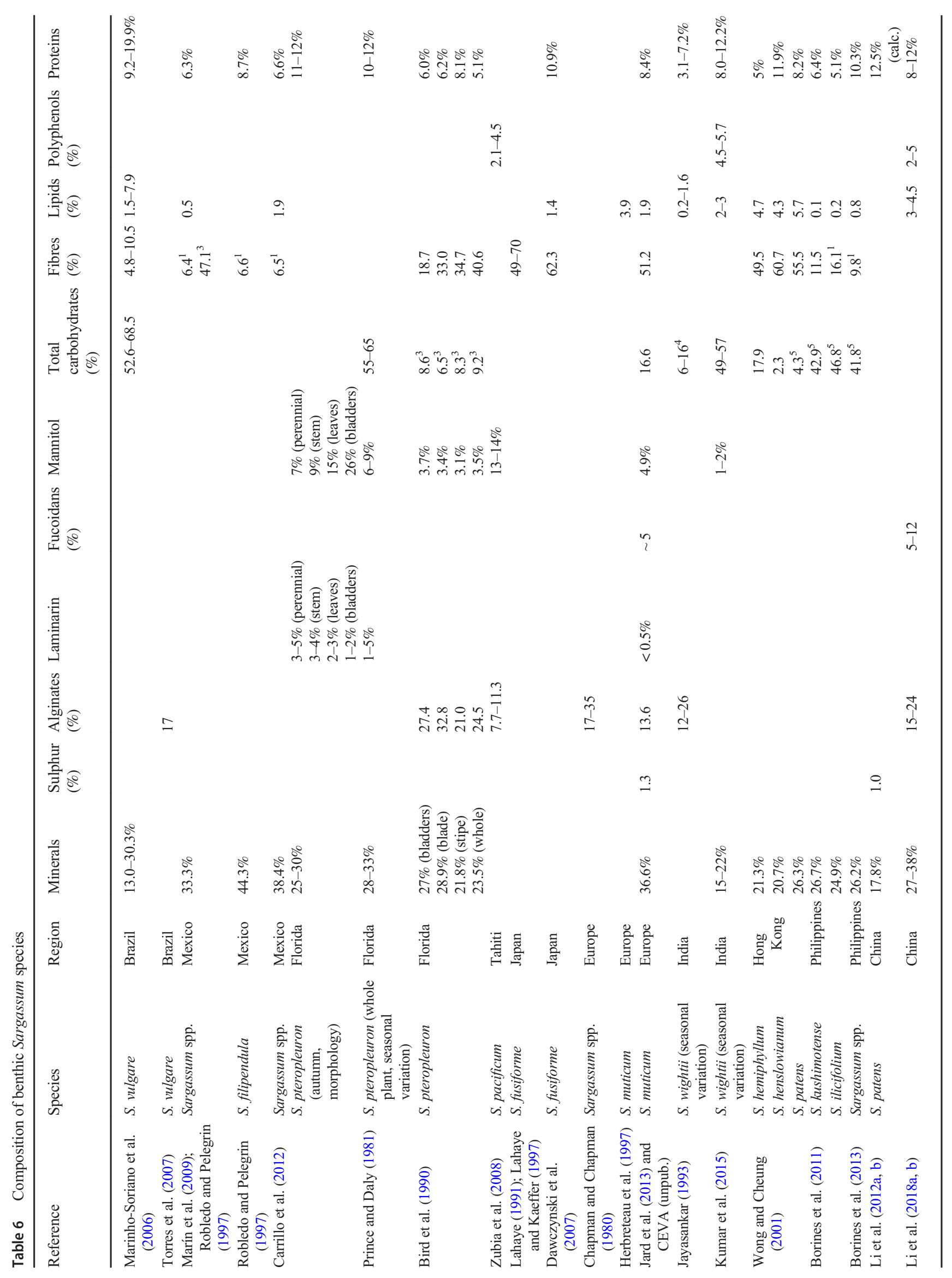




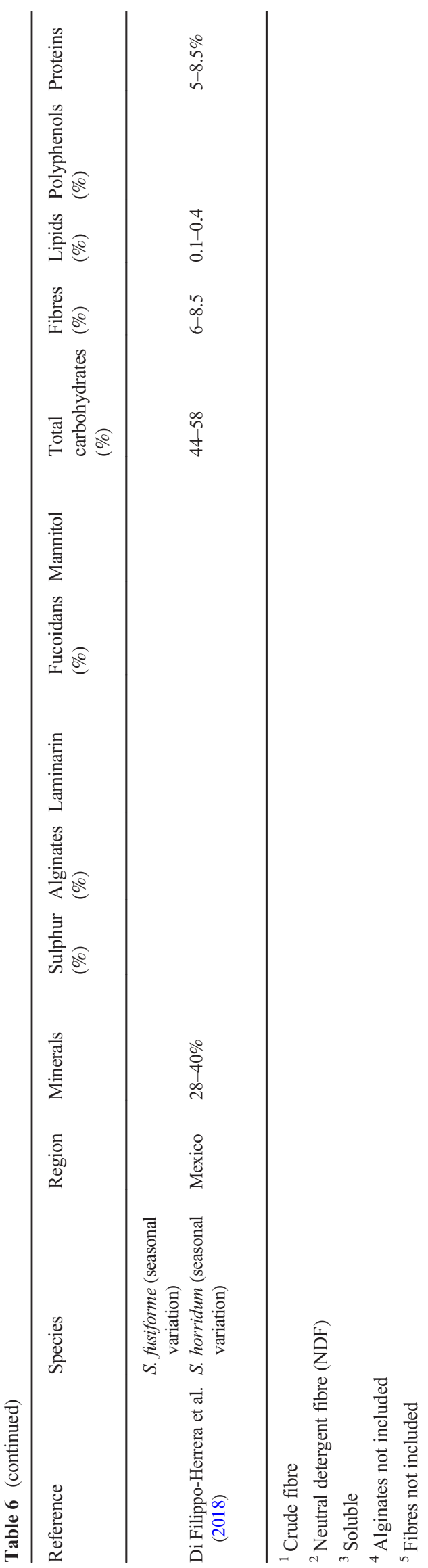

Its content varies strongly, depending on season and on the seaweed reproduction cycle, but it can reach over $30 \%$ in members of the Laminariales in autumn. The laminarin content reported in various species of Sargassum appears to be lower, even if it has rarely been determined. Only one study provides a detailed analysis of the laminarin content in S. pteropleuron from Florida (Prince and Daly 1981), which varies between $2 \%$ in spring/early summer and $4 \%$ in autumn. The laminarin content is high in the perennial part of the seaweed $(2.5-5 \%)$, whilst its content in the annual and reproductive portions remained much lower. Other authors have also demonstrated the presence of laminarin in S. pallidum (Ye et al. 2013) or S. fusiforme but neither accurately determined their content, even if Jin et al. (2017) showed that glucose proportion reaches its maximum in August. It should also be noted that these variations, related to seaweed morphology and to the reproduction cycle of benthic Sargassum species, should not necessarily be extrapolated to pelagic species, and that different patterns might be observed.

Laminarin is processed industrially for its capacity to stimulate the immune defences of plants and is also studied for its biological properties. It is also usually well metabolized by various organisms or can be hydrolyzed to glucose for further fermentation, making it an interesting starting material for energy applications such as biofuels or biogas.

Mannitol Mannitol is another storage carbohydrate. It is a polyol representing the first storage step in the photosynthetic chain, and which also plays an important role as an osmoprotectant in seaweed. Mannitol contents ranging from 3 to $14 \%$ have been described for Sargassum spp. (Zubia et al. 2008; Saha and Racine 2011) depending on season, geographies and species. As for laminarin, mannitol distribution throughout the seaweed thallus also exhibits strong variations depending on part and growth/reproduction cycle (Prince and Daly 1981).

Mannitol is sometimes co-extracted commercially by alginate producers (mostly in China) for food and pharmaceutical applications, when its content is sufficiently high to make it viable. However, it suffers from competition with the chemical route (hydrogenation) or biotechnological route from starch or sugar (Saha and Racine 2011; Varzakas et al. 2016). It is also one of the main constituents proposed as a bioactive by producers of plant biostimulants derived from brown seaweed (Sharma et al. 2014).

\section{Proteins}

The protein content of various seaweeds is usually calculated by determining nitrogen content using the Kjeldahl method (or sometimes Dumas) and applying the standard factor of 6.25 used for terrestrial plants. However, this factor might be slightly overestimated for those seaweeds which contain a 
a)

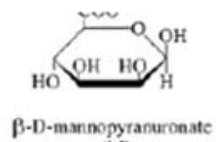

(M)

b)

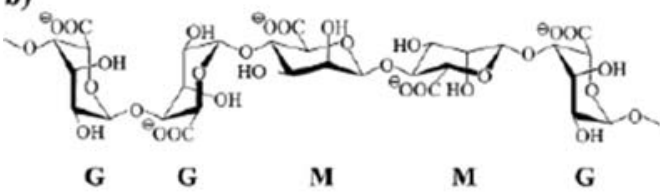

c)

GMMMMGGGGGGGMGMGMGMGMMMMG d)

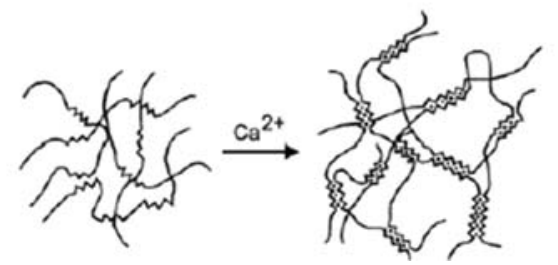

Fig. 3 Alginate molecular structure. a Alginate monomers (uronic acids: $\beta$-D-mannopyranuronate $M$ vs. $\alpha$-L-gulopyrunuronate $G$ ). b Macromolecular conformation of the alginate polymer. c Chain sequences; block co-polymer structure (Draget et al. 1996). d Calciuminduced gelation of alginate: schematic representation in accordance with the "egg-box" structure (Christensen et al. 1990)

relatively high content of acidic amino acids (Schiener et al. 2015) and for which non-proteic nitrogen represents 10-20\% of nitrogen (Lourenco et al. 2002). Therefore, the nitrogen-toprotein conversion factor varies depending on species and season (Schiener et al. 2015; Angell et al. 2016) and a more realistic universal factor of 5 was recently proposed by Angell et al. (2016). Nevertheless, the traditional 6.25 factor is still often used. It might be slightly overestimated but facilitates comparisons with older studies. As for many brown seaweeds, the protein content of some Sargassum species is relatively low, usually ranging from 5 to $2 \%$ (Table 5), even if higher values have occasionally been reported.

\section{Lipids}

From a qualitative perspective, seaweed lipids are different from terrestrial plant lipids. Seaweeds possess elongasedesaturase complexes with the ability to synthesize longchain unsaturated fatty acids (e.g. C20 and C22 $\omega$-3 fatty acids). Another peculiarity of various seaweeds is a relatively low proportion of triglycerides (the most common lipids in plants) and significant fractions of phospholipids and glycolipids. Yet, the overall lipid content in seaweed is low, usually $1-3 \%$ of dry weight, even if some species such as Ascophyllum nodosum can contain up to 5\% lipids (Dawczynski et al. 2007; Holdt and Kraan 2011).

In Sargassum spp., lipid contents are usually in the range of $0.5-5 \%$ (Table 5), even if higher values have been observed (Wong and Cheung 2001; Marinho-Soriano et al. 2006). It should also be noted that analytical methods differ between studies, which may impact results (e.g. methanol extractions of lipids which may co-extract polyphenols). Beyond fatty acid derivatives, the unsaponifiable fraction of Sargassum spp. tissues also contains sterols (Aknin et al. 1992; Guerra Dore et al. 2013), terpenoids (Balboa et al. 2013; Oyesiku and Egunyomi 2014), tocopherols and carotenoids such as fucoxanthin (Le Lann 2009; Heo et al. 2010; Yoon et al. 2012; Balboa et al. 2013).

\section{Polyphenols}

Brown seaweeds, and in particular Fucales (to which Sargassum species belong), are known for their high contents of polyphenols. These polyphenols are mostly composed of phlorotannins, oligomers and polymers of phloroglucinol.

Numerous studies have explored the anti-oxidant activity of various Sargassum extracts (Budhiyanti et al. 2012; Balboa et al. 2013, 2014) or even the structures of the polyphenols present in these extracts (Keusgen et al. 1997; Li et al. 2017b). However, even if the extraction processes are described, most authors focus on activity testing but do not determine the extraction yields, thus limiting the ability to determine the polyphenolic content in the seaweed. Polyphenol contents of up to 5\% and more have been reported for Sargassum species (Connan et al. 2006; Balboa et al. 2013; Tanniou et al. 2013; $\mathrm{Li}$ et al. 2018a). Nevertheless, the content seems to be generally lower in pelagic species such as $S$. natans and $S$. fluitans, with contents usually below $1 \%$ (Table 6 ), which is consistent with their "yellow" colour, whilst seaweed rich in polyphenols are much darker.

Polyphenol extracts from brown seaweed are mostly used for cosmetic applications and food supplements. Whilst their relatively low content in pelagic Sargassum spp. might limit their potential extraction, it can also positively affect the extraction and purification of other seaweed components.

\section{Current and potential applications for Sargassum spp.: technical and regulatory constraints}

\section{Food and food supplements}

\section{Sargassum consumption}

Of the multiple Sargassum species present throughout the world, only one is consumed to a significant extent. As previously mentioned, S. fusiforme, also known as Hizikia fusiforme, hiziki or hijiki, is a traditional food from 
Southeast Asia, exported throughout the world. Although it can be sold in its basic dry form, it is usually not directly consumed but rather used as raw material for further processing. S. fusiforme is traditionally boiled for several hours to remove astringent compounds (Nisizawa et al. 1987). This process also significantly impacts water-soluble compounds and helps reduce heavy metals and arsenic content (Hanaoka et al. 2001; Ichikawa et al. 2006).

Nevertheless, other Sargassum species, including S. fluitans and S. natans, are described as being consumed in the Caribbean as well as on the Pacific coast, e.g. S. vulgare, S. fluitans, S. natans, S. platycarpum, S. cymosum, S. filipendula, S. liebmannii, S. polycystum and $S$. polyceratium (Radulovich et al. 2013; Pereira 2016), but their peculiar taste and bitterness are mentioned. They are consumed fresh or rehydrated, fried, possibly after boiling or even as flour in tortillas. Other Sargassum species have also been considered as a potential food source, such as $S$. wightii in India (Kumar et al. 2015).

\section{Regulatory constraints}

There are no harmonized seaweed/algal regulations in Europe. The suitability of an algae for human food consumption is governed by the so-called "Novel Food" Regulation (Regulation (EU) 2015/2283), which applies to food and ingredients which were not consumed to a significant degree in Europe before May 15, 1997. Whilst S. fusiforme was consumed in Europe before 1997 and is listed as "not novel", S. fluitans and S. natans are not listed and would require evaluation before being placed on the market in Europe (including some Caribbean territories where pelagic Sargassum species are present).

There are also no specific regulations in the USA for edible seaweed. Some species of brown (21CFR184.1120) and red (21CFR184.1121) algae are considered generally recognized as safe (GRAS) and are allowed as food additives. However, this covers only a limited amount of species, which have to be dried and ground or chopped and used as a flavour enhancer or flavour adjuvant. Some kelp species are also authorized as a source of iodine with maximum daily iodine intake (21CFR172.365). These additives have to fulfil the criteria for kelp as defined in the Food Chemical Codex. Some provisions can also be found in regulations relating to organic food (7CFR205.606). Nevertheless, uncertainty remains high as to which species can actually be consumed (Janasie 2018).

Whether or not the seaweed species is specifically allowed for human consumption, it also has to fulfil the relevant food product regulations, especially with respect to heavy metals and arsenic (Table 7). Maximum levels of contaminants are governed by general food laws, unless stated otherwise in specific regulations. Recommendations have also been published in France relative to the presence of heavy metals, arsenic and iodine, and serve as a reference across Europe in the absence of European regulations. Also, even if S. fusiforme consumption is authorized worldwide, a number of food safety agencies (UK, Ireland, Canada, Hong Kong, New Zealand, Australia), have issued warnings regarding the risks presented by its high arsenic content (Food Standards Australia New Zealand 2016).

\section{Quality and supply}

\section{Heavy metals, arsenic and iodine in Sargassum spp.}

Arsenic Sargassum species are known to present high contents of arsenic and inorganic arsenic, even in pristine waters, which can limit their use in food applications (Hanaoka et al. 2001; Ichikawa et al. 2006; Dawczynski et al. 2007; Grinham et al. 2014). Sargassum fusiforme, traditionally consumed in Asia, has been the most thoroughly studied. Ichikawa et al. (2006) describe contents of 40-80 ppm total arsenic in seaweed from China, Korea and Japan, whilst Almela et al. (2006) found contents ranging from 70 to $150 \mathrm{ppm}$ total arsenic (40-120 ppm inorganic) in Japanese hijiki imported into Spain. Hanaoka et al. (2001) even describe total arsenic contents exceeding $200 \mathrm{ppm}$, mostly present in the most toxic inorganic form. Data relative to other species are more scarce but exhibit similar levels (Table 3). Arsenic levels in the order of $80-150 \mathrm{ppm}$ total arsenic are also regularly observed in Sargassum spp. from the Caribbean (Michel 1985; Dawczynski et al. 2007; García-Sartal 2012), including a significant proportion of inorganic arsenic (40-70 ppm). This elevated arsenic content also led ANSES, France's Food Safety Agency, to recommend exclusion of any food/feed uses of Sargassum spp. from the Caribbean (ANSES 2017).

Traditional processes of soaking and boiling applied to S. fusiforme present the advantage of significantly reducing their arsenic content. Nonetheless, Hanaoka et al. (2001) have shown that washing and soaking could reduce total arsenic by 30 to $60 \%$. It was also shown that cooking can decrease total arsenic content by up to $90 \%$ depending on temperature and $\mathrm{pH}$ (Ichikawa et al. 2006; Katayama 2015). Nevertheless, arsenic concentrations in the seaweed after processing can still exceed regulatory levels.

Cadmium Whilst cadmium content in Sargassum spp. is of lower concern, when compared to arsenic, it still tends to exceed regulatory thresholds or recommendations (e.g. $0.5 \mathrm{ppm}$ in France), with contents measured in the 0.52.0 ppm range (Almela et al. 2006; Dawczynski et al. 2007; 
Table 7 Maximum levels of arsenic, heavy metals and iodine in algae authorized for human consumption $\left(\mathrm{mg} \mathrm{kg}^{-1}\right)$

\begin{tabular}{|c|c|c|c|c|}
\hline Compound & $\begin{array}{l}\text { France } \\
\text { Food }\end{array}$ & $\begin{array}{l}\text { Europe } \\
\text { Supplements }\end{array}$ & $\begin{array}{l}\text { USA } \\
\text { Additives }\end{array}$ & China \\
\hline Inorganic arsenic $\left(\mathrm{As}_{\mathrm{i}}\right)$ & 3 & - & 3 & 1 \\
\hline Cadmium $(\mathrm{Cd})$ & 0.5 & 3 & & 1 \\
\hline Mercury (Hg) & 0.1 & 0.01 & & \\
\hline Lead $(\mathrm{Pb})$ & 5 & 3 & 10 & \\
\hline Tin $(\mathrm{Sn})$ & 5 & & & \\
\hline Total heavy metals (as $\mathrm{Pb}$ ) & & & 40 & \\
\hline Iodine (I) & 2000 & & $1000-5000$ & \\
\hline PAH-4 (polycyclic aromatic hydrocarbons) & & 0.05 & & \\
\hline Chlordecone & 0.01 & 0.01 & & \\
\hline References & $\begin{array}{l}\text { (CSHPF 1990; } \\
\quad \text { AFSSA 2009) } \\
\text { Regulation (EC) 396-2005 }\end{array}$ & $\begin{array}{l}\text { Regulation (EC) 629/2008 } \\
\text { Regulation (EU) 2015/1933 } \\
\text { Regulation (EC) 396-2005 }\end{array}$ & $\begin{array}{l}\text { Food Chemical } \\
\text { Codex } 3^{\text {rd }} \text { Ed }\end{array}$ & (Cherry et al. 2019) \\
\hline
\end{tabular}

Holdt and Kraan 2011), and sometimes exceeding this level (Table 2).

Lead As illustrated in Table 2, the content in Sargassum spp. around the globe regularly exceeds $10 \mathrm{ppm}$, which is above the limits set in most food regulations.

lodine Whilst the iodine content in Sargassum spp. can occasionally exceed regulatory thresholds with levels of up to $6000 \mathrm{ppm}$ (Hou and Yan 1998), this is not uncommon for brown seaweed. It is also to be expected that industrial washing/soaking processes significantly decrease the iodine content, as already demonstrated for other species (Stévant et al. 2018), although this was not specifically considered in soaking/cooking studies related to arsenic.

\section{Biomass availability and quality}

Beyond the strictly regulatory aspects mentioned previously, edible seaweeds are generally cultivated or harvested from the wild as attached, benthic species. Both collection of beachcast and possibly partially degraded Sargassum spp. and even harvesting of floating Sargassum spp. rafts raise numerous quality concerns: uncertain quality and food safety, lack of traceability, unknown history of growth and potential contaminations and so on.

\section{Feed}

\section{Use of Sargassum spp. in animal feed}

Various studies covered the inclusion of Sargassum spp. in animal nutrition, covering both animal performance and immunity aspects as well as product quality. Nevertheless, it should be noted that longer-term studies might be required to evaluate the potential impact of contaminants, and in particular arsenic, which was not usually quantified in the seaweed meals.

Poultry Carillo et al. (2012) described the use of 4-8\% of Sargassum spp. in the diets for hens, which reduced the egg cholesterol content, whilst not affecting productive variables and the egg's physical quality. However, egg productivity was slightly reduced. Choi et al. (2014) also observed improved growth parameters and reduced mortality of broiler chickens with a diet enriched with $0.5 \%$ of $S$. fusiforme processing byproducts (with or without fermentation).

Ruminants Sargassum spp. could be incorporated at up to $30 \%$ in the diets of sheep (Marín et al. 2009) and 25\% for goats (Casas-Valdez et al. 2006) with no significant difference in feed intake, feed conversion ratio, growth performance and diet digestibility. Palatability remained good, but water consumption was increased, likely due to the elevated mineral content. More recently, $4 \%$ inclusion of S. latifolium was shown to improve stress resistance of sheep by regulating thermo-respiratory and inflammatory response (Ellamie et al. 2020).

Fish and shrimp Multiple studies evaluated the impacts of Sargassum spp. on growth performance and immunity of various aquatic species. For example, $6 \%$ of $S$. fusiforme in olive flounder diet (Pham et al. 2006; Kim et al. 2014) increased growth rate (although not significant vs. control) as well as disease resistance during challenge tests. Inclusion of $2-4 \%$ of $S$. wightii in the diet of Asian seabass fingerlings also brought major improvements in disease prevalence when challenged with Aeromonas hydrophila (Kodithuwakku et al. 2017). Up to $7.5 \%$ of 
S. ilicifolium was also fed to rainbow trout without negative impact (Zamannejad et al. 2016). Ma et al. (2005) investigated high inclusion levels of $S$. siliquastrum $(30 \%)$ in silver seabream production to enhance their marine taste by increasing bromophenol content. In shrimp aquaculture, low-level inclusion $(0.5 \%)$ of $S$. filipendula improved resistance to thermal shock (Schleder et al. 2017), whilst $0.5 \%$ S. horneri upregulated immunity genes and growth performance (Lee et al. 2020). CruzSuárez et al. (2008) have also reviewed multiple studies with $2-10 \%$ inclusion of various Sargassum species and their impacts on growth performance, survival rates and immunity. The use of various Sargassum spp. extracts, rich in fucoidans, is also reported for anti-bacterial and anti-viral activity (Immanuel et al. 2012), which might be correlated with the capacity of FCSPs to reduce oxidative stress and modulate inflammation. Wang et al. (2018b) demonstrated that FCSPs extracted from S. fusiforme had a strong protective effect against $\mathrm{H}_{2} \mathrm{O}_{2}$ stimulated oxidative stress in vivo, in zebrafish. Other authors evaluated the effects of FCSPs from $S$. horneri and $S$. fusiforme in LPS-stimulated or virus-infected RAW264.7 mouse macrophage cells or zebrafish embryo models, demonstrating the downregulation of toxicity, modulation of NF- $\mathrm{kB}$ signalling cascade and reduction of pro-inflammatory cytokine production (Wen et al. 2016; Chen et al. 2018a, b; Sanjeewa et al. 2018).

\section{Regulatory constraints}

In Europe, Commission Regulation (EU) n ${ }^{\circ}$ 68/2013 established the catalogue of feed materials and allowed for the inclusion of various algal forms (fresh, dried, algal meal, algae extracts, etc.) without specifying any restrictions on species which could be incorporated (Table 8).

In the USA, the Food, Drug, \& Cosmetic Act requires that any substance that is added to or is expected to become a component of animal food, either directly or indirectly, must be used in accordance with a food additive regulation unless it is GRAS for that intended use, which brings us back to the same uncertainty on species authorized for food use. The Association of American Feed Control Officials (AAFCO) has specifically approved dried kelp from the families Laminariaceae and Fucaceae for use as ingredients in livestock feed, but not Sargassaceae (USDA National Organic Program 2013).

\section{Quality and supply}

\section{Heavy metals, arsenic and iodine}

Arsenic As for food applications, arsenic content appears to be a major limitation for the use of Sargassum spp. in feed applications. The arsenic content, and particularly the content of inorganic arsenic, largely exceeds the maximum values permitted in Europe, whilst other countries may not have specific regulations. Moreover, the processing costs related to the treatments for reducing arsenic content would be difficult to bear for feed ingredient manufacturers.

Natural and anthropogenic contents of cadmium may also exceed the maximum values, as well as lead content, whilst iodine content might also be a concern for formulators, limiting inclusion levels (but this is also the case for other brown seaweed species currently available and used in this sector).

\section{Biomass availability and quality}

As for food applications, collection of beach-cast Sargassum and even harvesting of floating Sargassum spp. rafts raise numerous quality concerns: uncertain quality and food safety, lack of traceability, unknown history of growth and potential contaminations and so on. Nevertheless, if quality and safety concerns could be resolved, the large volumes available at limited cost could make sense for feed applications as a novel source of seaweed for nutrition and health.

\section{Cosmetics}

Sargassum spp. have been the object of numerous studies related to their potential cosmetic applications and evaluating various types of extracts and fractions. Whilst some authors have investigated the activity of specific compounds, others have explored the bioactive properties of Sargassum spp. crude extracts, without establishing the link between chemical composition of the extracts and the effects observed. Some examples are outlined below.

Anti-oxidant/anti-ageing Numerous publications have described the in vitro anti-oxidant properties of Sargassum FCSPs, for example for S. fusiforme (Jaswir et al. 2014; Chen et al. 2016; Wang et al. 2018c), S. ilicifolium (Wang et al. 2015) or S. filipendula (Costa et al. 2011, 2015). It should be noted that this may not be directly related to the sulphated polysaccharides, but rather to co-extracted polyphenols, which are also relevant for cosmetic extracts. FCSPs from $S$. fusiforme have been studied for their protective effects against UVB-induced skin damage in vitro, in human dermal fibroblasts and in vivo with hairless mice (Ji et al. 2017; Wang et al. 2018c; Ye et al. 2018). Other lipidic compounds like carotenoids, sterols and meroterpenoids have also been tested. For example, fucoxanthin extracted from S. siliquastrum showed a strong in vitro anti-oxidant and protective effect against oxidative stress (Heo et al. 2008) and a similar protective effect against UVB radiation on human fibroblasts (Heo and Jeon 2009). Other studies have 
Table 8 Maximum levels of arsenic, heavy metals and iodine authorized in algae for animal feed $\left(\mathrm{mg} \mathrm{kg}^{-1}\right)$

\begin{tabular}{llll}
\hline Compound & $\begin{array}{l}\text { France } \\
\text { Raw materials }\end{array}$ & Europe & $\begin{array}{l}\text { USA } \\
\text { Additives }\end{array}$ \\
\hline Total arsenic $\left(\mathrm{As}_{\mathrm{t}}\right)$ & 40 & 40 & 3 \\
Inorganic arsenic $\left(\mathrm{As}_{\mathrm{i}}\right)$ & $2^{*}$ & $2 *$ & \\
Cadmium $(\mathrm{Cd})$ & 1 & 1 & 10 \\
Mercury $(\mathrm{Hg})$ & 0.1 & 0.1 & 40 \\
Lead $(\mathrm{Pb})$ & 10 & 10 & \\
Total heavy metals $(\mathrm{as} \mathrm{Pb})$ & & & \\
Iodine $(\mathrm{I})$ & & $4-20 * *$ & \\
Dioxins and dioxin-like PCBs (ppt) & 1.25 & 1.25 & \\
PCBs & 10 & 0.01 & \\
Chlordecone & & Directive 2002/32/EC \\
References & 30 October 2013 ruling & Regulation (EC) 396-2005 & \\
& &
\end{tabular}

*Upon request of the competent authorities, the operator must perform an analysis to demonstrate that the content of inorganic arsenic is lower than $2 \mathrm{ppm}$. This analysis is of particular importance for the brown alga Hizikia fusiforme (sic)

**Added iodine in formulated feed depending on species: equines, $4 \mathrm{mg} \mathrm{kg}^{-1}$ (total); ruminants for milk production; laying hens, $5 \mathrm{mg} \mathrm{kg}^{-1}$ (total); fish, $20 \mathrm{mg} \mathrm{kg}^{-1}$ (total). Other species or categories of animals, $10 \mathrm{mg}$ $\mathrm{kg}^{-1}$ (total)

investigated the effects of fucosterol on UV-induced cell damage (Hwang et al. 2014). Plastoquinones and chromene from methanolic extracts of $S$. micracanthum have been shown to possess significant anti-oxidant activities (Iwashima et al. 2005). The inhibitory effect of sargachromanol E extracted from $S$. horneri was investigated on UVA-irradiated dermal fibroblasts. The results indicated that sargachromanol E oxidative stress and expression of collagenases showed interesting anti-ageing properties (Kim et al. 2012, 2013a).

Whitening In a study aiming to find new whitening agents, 43 marine algae were screened for their tyrosinase inhibitory activity. Four seaweed extracts, including S. siliquastrum, evidenced potent tyrosinase inhibitory activity similar to that of positive control (kojic acid). Sargassum siliquastrum extracts also exhibited excellent inhibitory effects on the pigmentation of zebrafish (Abdel-Fattah et al. 1974; Cha et al. 2011). Hypopigmenting properties of the ethanolic extract from $S$. serratifolium were found to be correlated to the presence of sargaquinoic acid as an active component (Azam et al. 2018). FCSPs are of interest for skin-whitening applications, and a study conducted with depolymerized fucoidans from S. fusiforme revealed that low-weight polysaccharide had higher anti-tyrosinase activity than the original polysaccharide (Chen et al. 2016).

Anti-pollution New kinds of tests are being developed for this recent trend in cosmetic products. Ethanolic extract of $S$. horneri was reported to increase in vitro the mouse macrophage cellular resistance to fine-dust-induced inflammation and oxidative stress, showing anti-pollution potential (Jayawardena et al. 2018). Alginic acid extracts from $S$. horneri were also shown to significantly reduce inflammatory response in keratinocytes exposed to urban dust aerosols (Fernando et al. 2018). This interest in Sargassum spp. usage in the cosmetic field can also be illustrated by the commercialization of various extracts (Table 9).

\section{Regulatory constraints}

Heavy metals Concerning heavy metals, there are no clear international regulations on maximum levels allowable as impurities. For example, in Europe, cosmetic products must not contain any of the substances listed in Annex II to Regulation (EC) No. 1223/2009, which includes heavy metals such as lead, cadmium, arsenic, antimony and mercury. However, traces of these compounds are often present in certain cosmetics and in make-up products, due, amongst other reasons, to the inclusion of mineral pigments. According to most national/international regulations, traces of heavy metals in cosmetic products are allowed if they are technically unavoidable, but explicit limits are not always listed.

Nevertheless, some countries have issued regulations or recommendations on this point, and a number of them have implemented maximum levels that should not be exceeded in final formulated cosmetic products based on "technically avoidable" concentrations. Table 10 summarizes the limit concentrations proposed by several national authorities.

Some countries are also beginning to tighten their limits, as illustrated by the recently revised limits in Germany, where Federal Office of Consumer Protection and Food Safety 
Table 9 Commercial and cosmetic ingredients based on Sargassum spp.

\begin{tabular}{lll}
\hline Ingredient name & Supplier & Description/claims \\
\hline Fuligo & Clariant & Sargassum fusiforme extract; firming, moisturizing, anti-ageing and anti-wrinkle agent \\
AT MaronWhite S & Athena & Hizikia fusiforme extract; skin moisturization, skin lightening \\
AT MaronUV S & Athena & Sargassum fulvellum extract; protective activities against UVB \\
Gulfweed extract & Dermalab & Sargassum fulvellum extract; anti-oxidant, anti-inflammatory agent \\
LOOKETHIC & Biocosmethic & Sargassum filipendula extract; anti-ageing, anti-wrinkle, anti-oxidant, anti-fatigue, protecting and soothing agent \\
PHYACTYL® & Gelyma & Sargassum muticum extract; protective agent, lightening/whitening \\
Pearl Alga & Odycea & Sargassum muticum extract; whitening agent \\
\hline
\end{tabular}

(BVL) considered that good manufacturing practices would allow lower technically avoidable levels (BVL 2017). If levels of these contaminants exceed those values, the safety report of the cosmetic product has to consider it and provide the evidence that they are safe for the consumer.

Whilst these maximum limits or recommendations do not apply to the raw seaweed material, it is clearly necessary to monitor the content of arsenic and heavy metals in any extracts produced from Sargassum spp. As cosmetic active ingredients are usually used at low levels (typically below 1-2\% for dry extracts), this reduces the risk of exceeding the thresholds, but the lower limits for arsenic or cadmium in Germany, which might also be applied in other countries, could be a risk. Some companies' manufacturing end products might also be requesting that the ingredients/actives themselves respect those limits.

Organic contaminants It should also be noted that all PAHs with carcinogenic properties are forbidden in cosmetic products in Europe, as well as chlordecone (Regulation (EC) No. 1223/2009_Article 15 and Annex 2).

IECIC list To be sold on the Chinese market, one of the largest markets for cosmetics worldwide and exhibiting significant growth, cosmetic products should only contain ingredients found on the Inventory of Existing Cosmetic
Ingredients in China, also known as the IECIC list (CFDA 2015). To date, only four Sargassum spp. extracts were listed on the IECIC list, i.e. S. filipendula, S. fusiforme, S. muticum and S. pallidum. The absence of $S$. natans and $S$. fluitans from this list means that most international manufacturers of cosmetic ingredients would avoid investing in those species, and that developments from these seaweeds might be limited to regional products. Whilst the registration of new ingredients is still an option, this is a very lengthy and uncertain process that few companies are willing to undergo.

\section{Quality and supply}

Beyond the regulatory aspects mentioned previously, quality, traceability and sustainability of the sourcing are key factors for cosmetic applications, as they are often part of the marketing of the product. Despite the significant interest of Sargassum spp. extracts for a wide range of cosmetic benefits, using Sargassum spp. blooms as raw material might be difficult to reconcile with these important determinants for cosmetic manufacturers. This is particularly true as a large number of benthic Sargassum species are available globally, with harvestable stocks largely sufficient for the small volumes required for cosmetic extracts, and some of these species
Table 10 Maximum acceptable levels of arsenic and heavy metals in final formulated cosmetic products $\left(\mu \mathrm{g} \mathrm{g}^{-1}\right)$

\begin{tabular}{lllll}
\hline Compound & Germany (1985) & Germany (2007) & Canada & Southeast Asia \\
\hline Lead $(\mathrm{Pb})$ & 20 & $2^{*}$ & 10 & 20 \\
Arsenic $(\mathrm{As})$ & 5 & $0.5^{*}$ & 3 & 5 \\
Cadmium $(\mathrm{Cd})$ & 5 & 0.1 & 3 & 5 \\
Mercury $(\mathrm{Hg})$ & 1 & 0.1 & $1^{* *}$ & 1 \\
Antimony $(\mathrm{Sb})$ & 10 & 0.5 & 5 & \\
References & (BGA 1985) & (BVL 2017) & (Health Canada 2012) & (ASEAN 2017) \\
\hline
\end{tabular}

*Levels of 5 ppm and $2.5 \mathrm{ppm}$, respectively, for some make-up products

**The impurity limit for mercury has been amended from 3 to $1 \mathrm{ppm}$ as per the Minamata Convention on Mercury signed by Canada on October 10, 2013 
are already listed in China. Sargassum spp. blooms might also be perceived negatively by end-users, worried by press and media coverage of pollution, heavy metals and toxic hydrogen sulphide emissions. Lastly, whilst the development of cosmetic ingredients from Sargassum spp. blooms might bring economic returns to the companies involved, the small volumes required would not have any significant impact on the volumes to be handled.

\section{Health applications}

As for cosmetic applications, Sargassum spp. have been the object of numerous studies related to their health properties and bioactive compounds. However, as stated by Liu et al. (2012) in the conclusion of their review, many studies lack proper phytochemical characterization of the extracts used.

Namvar et al. (2013) investigated the anti-proliferative and anti-angiogenesis properties of $S$. muticum polyphenols, whilst ethanolic extracts of $S$. serratifolium were also recently shown to have potential against certain osteoclastic bone diseases and osteoarthritis (Kim et al. 2018; Park et al. 2018). Other research teams focused on lipidic compounds and investigated fucoxanthin (Heo et al. 2010) or extracts of sterols (Buwono et al. 2018) for anti-inflammatory and analgesic properties, or hepato-protective properties of meroterpenoids from S. serratifolium (Lim et al. 2018).

However, many studies report the potential of FCSPs from Sargassum spp. with regard to their anti-oxidant and antimicrobial (Jaswir et al. 2014), anti-tumour (Costa et al. 2011; Yu et al. 2017; Fan et al. 2018b), immune-modulatory (Jeong et al. 2015; Chen et al. 2018a), anti-inflammatory (Guerra Dore et al. 2013; Chen et al. 2018b), anti-coagulant and anti-thrombotic (Athukorala et al. 2007; Guerra Dore et al. 2013), hepato-protective ( $\mathrm{Yu}$ et al. 2017), neuroprotective (Huang et al. 2017; Jin et al. 2018) or anti-viral (Preeprame et al. 2001; Thuy et al. 2015) activities.

Other Sargassum spp. polysaccharides have also been described for their prebiotic properties, e.g. laminarin or complex polysaccharides (Chamidah 2018; Fu et al. 2018).

\section{Regulatory constraints}

Holdt and Kraan (2011) wrote an extensive review in 2011 covering seaweed bioactives and the regulatory requirements around the development of new functional ingredients. Even if the overall regulatory framework remains relatively unchanged, some regulations have evolved, for example the new Novel Food Regulation in Europe and associated changes in the procedures for authorization of novel foods.

An additional difficulty, at least for Europe, would be that S. fluitans and S. natans are not yet considered as edible species, which may imply more extensive testing to demonstrate the safety of the ingredients. Moreover, heavy metal and arsenic levels in the final products will also be under scrutiny.

We will not cover the regulatory requirements for drugs, which would not be different when prepared from Sargassum versus other sources, but again contaminants might be a concern.

\section{Quality and supply}

The development of health products requires the highest quality standards (Holdt and Kraan 2011; Gellenbeck 2012; Wells et al. 2017), which can be an issue when starting from raw materials harvested from blooms containing potentially unknown contaminants. This point could possibly be solved by processing steps and extensive purifications if required.

Raw material variability might be even more challenging (Gellenbeck 2012; Wells et al. 2017), particularly for complex compounds like polyphenols or polysaccharides, and in particular for FCSPs. A very high reproducibility of composition and bioactivity is expected from health products, which might be easier to obtain from cultivated seaweed (Gellenbeck 2012), or at least controlled harvesting. The composition of complex molecules in seaweed found in drifting blooms is likely to present higher variability, due to various environmental factors such as geographical origin, nutrients and weather conditions. Specific metabolites like fucoxanthin would remain easier targets as their content may vary but not their composition.

\section{Agriculture}

\section{Direct spreading}

Beach-cast seaweed (fresh or partially dried) has been used historically in rural coastal areas, in order to amend the soil in fields close enough to the coast (uncharacterized blend of seaweed collected on the beach, especially in autumn after the first storms in Europe). This is the most direct and cheapest use and is still performed locally across the globe. When fresh Sargassum spp. are used, safety measures similar to those implemented for Ulva spp. should be taken. To prevent anaerobic fermentation and formation of hydrogen sulphide, seaweed should be spread within 24-48 h from collection and ploughed rapidly (ANSES 2011).

Direct spreading of seaweed requires the setting up of a nutrient management plan, which may take different regulatory forms depending on national regulations. It usually describes the farm(s), the zones where seaweeds will be spread and the conditions under which spreading will be performed. It should take into account the nitrogen, phosphorus and potassium contribution from the seaweed, and the plan is usually 
complemented with an agronomic follow-up to assess efficiency and required adjustments.

There is still a limited amount of scientific data relative to direct use of $S$. natans and $S$. fluitans in this context, but several questions have been raised with regard to their content of nutrients and contaminants. A study performed for DAAF Guadeloupe in 2011 (personal communications) showed adequate nitrogen and phosphorus inputs in beach-cast Sargassum spp. (expected to contain $S$. natans and/or $S$. fluitans) but flagged sodium content as a potential contributor to soil salinization. The report recommended an input of $20 \mathrm{tha}^{-1}$ for sugar cane, with spreading during the rainy season and 2 months before cultivation in order to allow sodium leaching. The same study also reviewed heavy metals, but lead, cadmium and mercury were not a concern from a regulatory perspective. A more recent study performed by IT2 (Tropical Technical Institute) and several partners in the French Caribbean also concluded that the addition of 10 to $20 \mathrm{t} \mathrm{ha}^{-1}$ of beach-cast Sargassum species (S. fluitans and/or $S$. natans) had no agronomic interest for cucumber, lettuce, banana, sweet potato and sugarcane, whilst presenting a risk of salinization and raising concerns with arsenic and, potentially, chlordecone. Consequently, a recommendation was issued to farmers to avoid using Sargassum (Sargasses and Agriculture 2018). Indeed, with total arsenic contents reaching $100-200 \mathrm{mg} \mathrm{kg}^{-1}$, of which a large part was inorganic, direct spreading of Sargassum spp. cannot be performed under the French regulation for organic amendments (limit of $18 \mathrm{mg}$ $\mathrm{kg}^{-1}$ total As) or even the European Regulation (limit of $40 \mathrm{mg} \mathrm{kg}^{-1}$ of inorganic arsenic) (see Table 8). In addition, even if this limit is not taken into account, the French annual limit of arsenic of $90 \mathrm{~g} \mathrm{ha}^{-1}$ year $^{-1}$ for organic amendments would limit the use to less than 1 ton $\mathrm{ha}^{-1}$ of seaweed, which presents little agronomic interest.

\section{Composting}

Composting is an aerobic method used to decompose fermentable organic materials, eliminating or reducing pathogens, reducing the waste material mass by evaporation and $\mathrm{CO}_{2}$ emission and transforming organic matter into humus. The compost obtained can be used as organic amendment/soil conditioner. Composting is usually performed on dedicated sites (possibly classified facilities for environment protection), where liquid phases (and sometimes gases) can be collected and treated. It generally consists of two phases: an active phase of aerobic fermentation (4-6 weeks), where the biodegradation is at its most active, with significant leaching of fermentation juices and atmospheric release (water vapour, $\mathrm{CO}_{2}$, ammonia, aerosols, etc.) and a maturation phase (4-6 months) with reduced aeration, where organic matter reaches a humic state and the compost stabilizes.
Composting of pure seaweed is known to be difficult (inadequate $\mathrm{C} / \mathrm{N}$ ratio (too low), high mineral content and salinity, etc.) and generally requires the addition of other organic wastes (typically green waste, wood or straw, acting as structuring material and providing organic matter). The proportion of plant waste should be adapted according to the seaweed species to provide adequate organic content and porosity for proper aeration (Han et al. 2014; Cole et al. 2016).

A number of studies have been conducted specifically with Sargassum spp. A study was carried out in 1984 with S. muticum (Brault et al. 1984) and various types of green waste (75-85\% seaweed in the mix). The technical feasibility of using S. muticum as the main constituent for compost production conforming to the French NFU 44-051 standard for organic amendments was demonstrated, despite a lack of economic value if the seaweed had to be harvested. Various technical parameters relative to seaweed preparation were also tested. Pressing or partial drying of the seaweed to $20-25 \%$ dry matter was a pre-requisite to reach sufficient temperature during the fermentation phase. Washing to reduce the sodium content and conductivity was also efficient, but detrimental to other compounds of interest for fertilization (e.g. potassium). Co-composting of $S$. natans and S. fluitans with food waste and wood chips was also investigated at the University of Texas (Sembera 2013), but limited amounts (2\%) of seaweed were used and the impact was limited. In a more recent study, the same authors increased incorporation to $4 \%$ (which remains relatively low), obtaining good quality compost (Sembera et al. 2018). Washing of the seaweed had no significant impact on salinity, which remained in the lower range accepted by the US Composting Council.

More recently, massive strandings in the Caribbean incited a number of compost facilities to incorporate Sargassum spp. in their products. A case in point can be found in Martinique, where three companies (Holdex, Idex and Société Martiniquaise des Eaux) obtained the authorization to incorporate the collected seaweed in their composts. Sand and excess sodium had to be considered, but co-composting with green waste or sugarcane bagasse with up to $10 \%$ fresh Sargassum spp. turned out to be feasible, whilst maintaining products complying with standards NFU 44-051 and 44-551. This inclusion level may seem relatively small, in order to cope with massive strandings, but it also allows relatively easy integration into existing composting units, which have to run on alternative feedstocks during periods where no strandings occur. New trials performed under strongly hypoxic conditions were also performed by Holdex and exhibited interesting composting efficiency (personal communications). The results will be published in the near future.

Whilst arsenic might be a concern for the direct spreading of Sargassum spp., co-composting with a moderate content of Sargassum spp. (e.g. $\leq 10 \%$ ) "mathematically" brings it down to levels below or close to the limit set in France, for example 
$18 \mathrm{mg} \mathrm{kg}^{-1} \mathrm{dw}$, and in typical ranges for soils. In addition, a significant fraction of the arsenic is likely to leach out during the composting phase, as shown for other arsenic-rich plants (Cao et al. 2010). Some arsenic may also volatilize as arsine gas $\left(\mathrm{AsH}_{3}\right)$ or its volatile methylated forms after conversion by microorganisms, although volatilization in aerobic conditions is expected to remain low (Naidu et al. 2006; Cao et al. 2010; Cullen and Reimer 2016). However, the presence of arsenic in compost leachates should be monitored, and specific remediation treatments might be required. Volatilization, whilst increasingly considered as an arsenic mitigation strategy, will also subsequently lead to oxidation of the released arsine derivatives into non-volatile forms returning to the soil through particle deposition and rain (Punshon et al. 2017).

\section{Formulated extracts (liquid fertilizers, biostimulants, etc.)}

Brown seaweed extracts, sold as seaweed concentrates or formulated biostimulants, have a significant history of use for plant growth and health (Craigie 2011; Sangha et al. 2014; Sharma et al. 2014; Battacharyya et al. 2015). Seaweed polysaccharides, including laminarin and FCSPs, can also act as elicitors, triggering plant immune response by stimulating defence enzymes (Zheng et al. 2020). Beyond compounds of interest for biostimulation (phytohormones, polysaccharides, etc.), the species used were also strongly influenced by their availability either as wild harvestable resources or as beachcast seaweed (Zemke-White et al. 2004; Stirk and van Staden 2006). The most commonly used species in commercial products are Fucales and Laminariales. In the Northern Hemisphere, Ascophyllum nodosum is the most frequent (Northwest Europe, North America) and, to a lesser extent, Laminaria spp., whereas in the Southern Hemisphere, products are usually based on Ecklonia spp. (New Zealand, South Africa) and Durvillaea potatorum (Australia).

Sargassum spp. are far less common, although the Chinese company Beijing Leili Marine Bioindustry proposes a range of Sargassum-based products, and local products are available in the Caribbean (e.g. Santa Lucia-based Algas Organics) or in Indonesia, for example. They are also less covered in the scientific literature, even if a number of recent studies describe interesting results of $S$. wightii extracts on cluster bean (Vijayanand et al. 2014) or okra (Tensingh Baliah et al. 2017). An optimal concentration may also be necessary, as both studies show that beyond certain levels, the addition of these extracts might be detrimental. Sargassum vulgare extract was also shown to improve yield and quality of red radish (Mahmoud et al. 2019), but germination of mung bean was delayed by $S$. horridum extract (Di Filippo-Herrera et al. 2018) and $S$. muticum extracts did not stimulate mung bean and pak choi (Sharma et al. 2012). Another recent study using several Sargassum species as solid and liquid extracts for rice growth did not significantly improve harvest yields, even if impacts on vegetative growth were observed (Sunarpi et al. 2019).

Regulation for organic fertilizers, compost and biostimulants

Different limits may apply to Sargassum-based agricultural products depending on countries and product types (Table 11). For example, compost in the USA falls within the regulation of biosolids (40 CFR 503) with the same limits as for sewage sludge, whilst in the case of France, specific limits apply in the standards for organic fertilizers and composts.

Fertilizing products and biostimulants placed on the market in Europe must comply with the newly introduced regulation (EU) 2019/1009 (for CE-marked products) or with national regulations/standards (e.g. by complying with specific standards or through specific authorization procedures). In addition, all substances incorporated into the EU fertilizing product, e.g. Sargassum-based extracts, need to have been registered pursuant to Regulation (EC) No. 1907/2006 concerning the Registration, Evaluation, Authorisation and Restriction of Chemicals (REACH) and may require additional testing depending on production volumes.

\section{Bio-based materials}

There are a number of uses of Sargassum species as raw materials for bio-based materials, although these are not extensively covered in the scientific literature. They are usually driven by individual initiatives and the creation of dedicated companies. To cite just a few, Sargassum sp. from the Caribbean region is currently being processed or explored for its use in bio-based or partially bio-based plastics (AlgoPack, Renovare), in papers and boards (Sargánico, Sargasse Project, The Marine Box) or for the production of Sargassum bricks in Quintana Roo, Mexico (Sargablock).

Regulatory constraints are too dependent on product types and sectors of applications to be covered here, but migration of contaminants, for example, should be closely monitored for packaging applications or any products coming into contact with food, as well as final disposal for products that would be produced in large volumes.

\section{Energy}

\section{Biogas production}

Anaerobic digestion presents the advantage of being able to ferment complex organic compounds and can be applied to a broad range of animal and vegetal biomass. Whilst converting potential organic waste, it can be seen as an environmentfriendly means of access to renewable energy or heat via the production of biogas (methane and $\mathrm{CO}_{2}$ ). 
Table 11 Maximum levels ( $\mathrm{mg} \mathrm{kg}^{-1}$ dry weight) and maximum flux $\left(\mathrm{g} \mathrm{ha}^{-1}\right)$ of arsenic, heavy metals and contaminants in fertilizers, organic amendments, composts and plant biostimulants

\begin{tabular}{|c|c|c|c|c|c|}
\hline \multirow[t]{2}{*}{ Compound } & \multicolumn{3}{|l|}{ France } & \multirow{2}{*}{$\begin{array}{l}\text { Europe } \\
\text { Max level }\end{array}$} & \multirow{2}{*}{$\begin{array}{l}\text { USA } \\
\text {-Compost } \\
\text { Max level }\end{array}$} \\
\hline & Max level & Max annual flux & Max 10-year flux & & \\
\hline Total arsenic $\left(\mathrm{As}_{\mathrm{t}}\right)$ & 18 & 270 & 900 & & 41 \\
\hline Inorganic arsenic $\left(\mathrm{As}_{\mathrm{i}}\right)$ & & & & 40 & \\
\hline Cadmium $(\mathrm{Cd})$ & 3 & 45 & 150 & 1.5 & 39 \\
\hline Chromium (Cr) & 120 & 1800 & 600 & $2(\mathrm{Cr}(\mathrm{VI}))$ & - \\
\hline Mercury (Hg) & 2 & 30 & 100 & 1 & 17 \\
\hline Lead $(\mathrm{Pb})$ & 180 & 2700 & 9000 & 120 & 300 \\
\hline Nickel (Ni) & 60 & 900 & 3000 & 50 & 420 \\
\hline \multicolumn{6}{|l|}{ Total heavy metals (as $\mathrm{Pb}$ ) } \\
\hline Fluoranthene & 4 & 6 & & & \\
\hline Benzo(b)fluoranthene & 2.5 & 4 & & & \\
\hline Benzo(a)pyrene & 1.5 & 2 & & & \\
\hline References & \multicolumn{3}{|c|}{$\begin{array}{l}\text { Standards NF U 42-001, NF U } \\
44-051 \text { and NF U 44-095 }\end{array}$} & $\begin{array}{l}\text { Regulation (EU) } \\
2019 / 1009\end{array}$ & $\begin{array}{l}\text { (US Composting Council) } \\
\text { Based on } 40 \text { CFR } 503\end{array}$ \\
\hline
\end{tabular}

In brown seaweeds, polysaccharides and carbohydrates (alginates, fucoidans, laminarin, mannitol) are the main substrate for this fermentation process. But as anaerobic digestion is relatively unspecific, other seaweed constituents such as proteins and lipids can also be degraded. Chynoweth and coworkers (2001) showed that seaweed can be relatively easily converted to biogas. Promising results were also reported for various seaweed species and genera: S. muticum (Gellenbeck and Chapman 1986), Laminaria hyperborea (Horn et al. 2001), Ulva sp. (Morand and Briand 1999; Morand et al. 2006) and Macrocystis pyrifera (Vergara Fernandez et al. 2008). Average conversion yield reported in various studies varies between 200 and $300 \mathrm{Nm}^{3}$ biogas per tonne of volatile matter (Briand and Morand 1997; Chynoweth 2002; Vergara Fernandez et al. 2008). In comparison with other biomasses commonly used for biogas production, this value is close to that found for manure, pig slurry or lignocellulosic residues.

However, amongst the algal genera studied, Sargassum spp. are not the best candidates. Jard et al. (2013) showed that S. muticum had the lowest methane yield amongst ten species from the Brittany coast, with $0.13 \mathrm{~L} \mathrm{CH}_{4} \mathrm{~g}^{-1}$ of organic matter, and similar values were found by Milledge and Harvey (2016). Other studies reviewed the anaerobic digestion of S. muticum in Europe (Oliveira et al. 2015; Soto et al. 2015; Milledge and Harvey 2016), but also S. fluitans and S. pteropleuron in Florida (Habig and Ryther 1983; Bird et al. 1990). This low methane yield might be explained by a relatively large proportion of insoluble fibres (recalcitrant to anaerobic digestion) and polyphenols (inhibitors), with low contents in digestible carbohydrates and proteins, and an inadequate $\mathrm{C}: \mathrm{N}$ ratio. Although most authors do not report particular problems with the composition of the biogas and product forms, these limited yields remain a major concern for any developments, especially as the high mineral content results in progressive filling of the digester (Jard et al. 2013; Soto et al. 2015). The use of co-substrates such as glycerol might improve conversion (Oliveira et al. 2015) but has not, to our knowledge, been significantly applied to seaweed biomass.

Other components of Sargassum spp. might negatively impact biogas production. For example, $\mathrm{H}_{2} \mathrm{~S}$ formation during anaerobic digestion is known to induce inhibitions, even if these inhibitions are often not observed with seaweed despite high $\mathrm{H}_{2} \mathrm{~S}$ concentrations (Montingelli et al. 2015), and yield losses are observed due to competition with sulphate-reducing bacteria (Cecchi et al. 1996). The presence of $\mathrm{H}_{2} \mathrm{~S}$ in the biogas can also trigger corrosion in co-generators, and specific treatments might be required (Peu et al. 2011; McKennedy and Sherlock 2015). Inhibition phenomena related to polyphenols have also been described with brown seaweed (Jard et al. 2013; McKennedy and Sherlock 2015; Soto et al. 2015), although the contents are relatively low in $S$. natans and $S$. fluitans. In a recent study, Milledge et al. (2019) confirmed that alginates were highly recalcitrant, and that the addition of phenolics further decreased conversion ratio, confirming their inhibitory properties. Minerals, especially sodium, might also induce inhibitions, although those usually occur at relatively high levels (Soto et al. 2015). Lastly, the presence of sand and foreign bodies can damage grinding equipment, pumps and digesters. In addition, as digesters require a stable feed to reach a stable methane production regime, irregular supply from strandings is far from ideal. A recent study also explored the possibility to fractionate $S$. muticum to obtain products of interest (biostimulants, FCSPs and polyphenols), with final solid 
residues which were shown to be more adequate for biogas production than the raw seaweed (Flórez-Fernández et al. 2020).

Taking into account the above-mentioned limitations, Sargassum spp. still appear to be a potential co-substrate in biogas production, but we are not aware of any industrial sites currently processing seaweed for biogas.

The fate of arsenic during biogas production still raises a number of questions. Various authors studied the anaerobic digestion of arsenic-rich sludge from wastewater treatment (Mohapatra et al. 2008), arsenic-rich plants (da Silva et al. 2019) or arsenic-containing sewage sludge (Weithmann et al. 2019). All authors concluded that there was a limited impact of the arsenic on methanogenic bacteria and digestion performance. Whilst some authors mention potential significant volatilization of arsenic (Mohapatra et al. 2008; Mestrot et al. 2013), most recent studies tend to show that arsenic volatilization remains very limited, often around or below 1\% of total arsenic (Mestrot et al. 2013; Clancy 2015; da Silva et al. 2019; Weithmann et al. 2019) and arsenic concentration in the biogas was largely below regulatory limits. Nevertheless, technical limits might be reached with very low levels of arsenic in the gas phase and risks of machinery failure and catalyst poisoning are reported (Weithmann et al. 2019). Also, as most of the arsenic is transferred to the aqueous phase, the digestate might require specific post-treatments, and it could also prevent it being used for fertilization.

\section{Hydrogen production}

Hydrogen production is another potential use of vegetal biomass, including algae. The mechanisms involved in this process are well described in a recent review by Xia et al. (2015) even if it targets microalgae more specifically. In the context of hydrogen production, the main limiting factors appear to be inhibition by ammonium, related to the presence of proteins in the algae biomass, but which should remain limited considering the low protein content in Sargassum spp. as well as concerns with the purity of the gas produced (especially related to the presence of $\mathrm{H}_{2} \mathrm{~S}$, sulphur compounds and ammonia), which need to be cleaned up before use.

\section{Bio-oil and biochar production (hydrothermal liquefaction, pyrolysis)}

Hydrothermal liquefaction (HTL) and pyrolysis are two conversion techniques for the production of bio-oils, allowing vegetal biomass to be converted into energetic substrate analogous to unrefined crude oil. Both techniques have been explored in recent years on seaweed biomass and, in particular, on Sargassum spp. (Li et al. 2010, 2012a, b; Kim et al. 2013b; Diaz-Vazquez et al. 2015; Ghadiryanfar et al. 2016; Biswas et al. 2018, 2020; Li et al. 2020). Their principles are different, but both techniques lead to relatively similar bio-oils (Saber et al. 2016). Pyrolysis is a thermal treatment at atmospheric pressure in the presence of oxygen. It should be performed on dry seaweed, but the pyrolysis itself can provide energy for the drying stage. HTL is a thermal treatment in aqueous conditions under pressure, which presents the advantage of not requiring preliminary seaweed drying. In this review, we will not cover the advantages and drawbacks of the two techniques on yield and quality of the bio-oil. Both require significant post-processing to cope, amongst others, with oxygen and nitrogen-containing compounds (Wang et al. 2013; Saber et al. 2016). During this refining step, usually via catalytic hydrotreatment, sulphur compounds are converted to $\mathrm{H}_{2} \mathrm{~S}$ (Biddy et al. 2013). Nevertheless, as these are purely thermo-chemical processes, and not biological ones, inhibition by ammonia and toxicity of sulphur compounds are not a concern as in biogas production, but they still need to be removed from the final products and may present similar risks for equipment (corrosion, deposition and so on) and catalysts. Transfer of contaminants to the gas phase during pyrolysis should also be considered, as it must in the case of combustion (see "Waste").

Depending on process parameters, various levels of biochars can be produced during these processes. They can be of interest for various applications, such as the production of porous, activated carbon (Xu et al. 2013; Biswas et al. 2018; Li et al. 2018b), which could be further used for electronics, agriculture or bioremediation applications. But, their level of impurities will have significant impact on potential uses. Although the possibility has not been significantly studied yet, these techniques could also be considered as a potential tool to concentrate some of the contaminants present in Sargassum spp., such as arsenic and heavy metals, in a concentrated aqueous phase or in dry ashes.

\section{Fate of arsenic and heavy metals in the processing of Sargassum spp. biomass: regulatory constraints}

\section{Fate of arsenic and heavy metals}

As discussed in the previous section, numerous applications are, or can be, considered for Sargassum spp. Except for a limited number of direct uses, any industrial processes applied to those seaweeds will generate wastes, co-products, water effluents and possibly gaseous effluents. Moreover, even direct applications may require temporary storage or cleaning/ drying steps which will themselves generate similar products/ effluents. Determining the fate of contaminants such as arsenic and heavy metals over those processes should be performed on a case-by-case basis. However, a number of 
regulatory aspects should be taken into account whilst assessing their industrial feasibility.

\section{Effluents and waste regulations}

\section{Waste}

Spent biomass from Sargassum spp. extraction can be considered as plant waste, seaweed or compostable material (depending on national regulations and on specific processes/ chemicals that might have been used) and, as such, be used for spreading on land or in fertilizers. In this case, the regulatory constraints already outlined for fertilizers and biostimulants would prevail. However, if they do not comply with these regulations (e.g. due to arsenic content), they might also have to be treated more specifically, or incinerated.

\section{Water}

Wastewater from seaweed processing has to be considered with care, especially as most soluble forms of arsenic, and particularly inorganic arsenic, are likely to be solubilized to a significant extent, as described earlier in this review for S. fusiforme treatments (Hanaoka et al. 2001; Ichikawa et al. 2006; Katayama 2015). Leachates from Sargassum spp. storage sites should also be monitored.

A good example is the case of a French processing plantproducing alginates and processing $50 \mathrm{kT}$ of Laminaria spp. per annum. The company improved their wastewater treatment unit in order to improve the quality of the water released into the environment, with a specific focus on arsenic content. The improved process, in turn, increased the arsenic content in the sewage sludge to $159 \mathrm{mg} \mathrm{kg}^{-1}$, which significantly impacted their sewage sludge-spreading plan (Préfecture du Finistère 2014). This example illustrates how large-scale processing of arsenic-rich Sargassum spp. species may imply significant work on effluent clean-up. Beyond biological treatment, various technologies for arsenic removal from contaminated waters have been described. They include ultrafiltration (mostly for drinking water due to elevated cost and sensitivity to fouling), precipitation with iron oxides or treatments with magnesium salts (e.g. $\mathrm{MgCl}_{2}$ ) (da Silva et al. 2019).

However, it is difficult to list general regulatory limits for contaminant content in effluents, as these limits depend on various factors:

- Effluents treated further in a municipal wastewater treatment plant or sent back to the environment

- Volumes of effluents produced, dilution

- Presence of contaminants or chemicals which might impact ecosystems or wastewater treatment efficiency
- Local limits: e.g. technologies in place and treatment capacity of the downstream municipal wastewater treatment plant

- Sectorial limits with norms set depending on the type of industries, and available/affordable technologies, e.g. US National Pretreatment Program and National Pollutant Discharge Elimination System (NPDES), European Best Available Techniques Reference documents (BREFs)

Companies usually have to register their uses and characterize/control their effluents (volumes, physicochemical parameters, composition, etc.) and apply for specific authorizations, which may come in several forms depending on national regulations, and the volumes/contaminants concerned (e.g. Facilities Classified for Environmental Protection (ICPE) in France, Industrial User Permit in the USA). Additionally, registers may have to be held for specific contaminants emitted or transferred to the environment (Table 12).

\section{Sewage sludge (biosolids)}

Disposal of sewage sludge usually depends on several parameters. In Europe they can be directly considered as fertilizers if their content complies with national or European norms. Alternatively, they can be integrated in spreading plans for sludge from wastewater treatment on agricultural land (Table 13), in which case their nutrient content also needs to be integrated in the local/farm nutrient management plan. Spreading on non-agricultural land can also be considered, sometimes with higher limits (e.g. 40 CFR 503.13 in the USA).

It should be noted that the European Union has no specific limits for arsenic in sewage sludge to be used in agriculture. However, although France does not regulate arsenic in sewage sludge either, the values allowed for fertilizers in France could be considered as a reference ( $90 \mathrm{~g} \mathrm{ha}^{-1}$ year $^{-1}$ over 10 years). In the example mentioned previously (Préfecture du Finistère 2014), sewage sludge from a seaweed processing plant in France reached $159 \mathrm{mg} \mathrm{kg}^{-1}$ of arsenic, which is above the

Table 12 Reporting thresholds $\left(\mathrm{kg} \mathrm{year}^{-1}\right)$ for arsenic and heavy metals released into the environment

\begin{tabular}{ll}
\hline Compound & France \\
\hline Lead $(\mathrm{Pb})$ & 200 \\
Arsenic $(\mathrm{As})$ & 20 \\
Cadmium $(\mathrm{Cd})$ & 10 \\
Chromium $(\mathrm{Cr})$ & 100 \\
Mercury $(\mathrm{Hg})$ & 10 \\
Nickel $(\mathrm{Ni})$ & 50 \\
Antimony $(\mathrm{Sb})$ & 10 \\
References & 31 January \\
& 2008 ruling \\
\hline
\end{tabular}


limit set in the USA for agricultural use, or for French fertilizers. However, with a spreading plan considering an average sewage input of $500 \mathrm{~kg} \mathrm{ha}^{-1}$ year $^{-1}$, the arsenic load is brought down to $80 \mathrm{~g} \mathrm{ha}^{-1}$ year $^{-1}$, below the maximum flux allowed in France, and 500 times below the cumulative loading rate allowed in the USA. But at this level, the contribution in nutrients is very low compared to standard sludge/compost input of 5-30 tha $\mathrm{ha}^{-1}$ and requires significant surfaces (3600 ha in their case). This is more a way of disposing of the waste, rather than a true contributor to the nutrient plan, even if other residues/compounds from the seaweed processing might have benefits for the plant.

Beyond these direct uses, sewage sludge can also be processed further to compost (e.g. complying with the norm NF U 44-095 in France), integrated into biogas production units or incinerated. Long-term arsenic immobilization could be improved further by preliminary treatment with calcium salts (e.g. lime) before sludge incineration (Fujita et al. 2000).

\section{Air}

Specific limits for arsenic and heavy metals are set for incineration of sewage sludge and wastes. For example, the US EPA determined limits (expressed in $\mu \mathrm{g} \mathrm{m}^{-3}$ ) for incineration of sewage sludge (40 CFR 503.43), which allow, depending on the system used, calculation of maximum levels of these compounds in the sewage sludge to be incinerated. Similarly, the European Directive 2010/75/EU establishes air emission limits for waste incineration plants and waste co-incineration plants for cadmium/thallium, mercury and the sum of other heavy metals including arsenic.

During incineration of biomass contaminated with heavy metals, they are mostly recovered as ash (mostly bottom ash and cyclone ash when cyclone is present), even if they are also found in fly ash (partly recovered on filters, although very fine fly ash will be lost with flue gas) (Nzihou and Stanmore 2013). Therefore, their loss is mostly in accordance with the efficiency of gas cleaning for particulates. However, more volatile metals like mercury, selenium and, to a lesser extent, arsenic can also be lost as vapours.

In the case of arsenic, retention in bottom and cyclone ash is relatively good up to $600{ }^{\circ} \mathrm{C}$ (Nzihou and Stanmore 2013) or even $800{ }^{\circ} \mathrm{C}$ (Gerstle and Albrinck 1982) but significantly decreases at higher temperatures, which should be avoided. However, controlling the combustion parameters (e.g. at $800-950{ }^{\circ} \mathrm{C}$ with high $\mathrm{O}_{2}$ content) can allow for the better capture of arsenic in fly ash through condensation/absorption on particulates and conversion into its less toxic As(V) form (Zhao et al. 2018). Incinerating with co-substrates rich in compounds such as calcium, or iron, is also reported to help reduce the toxicity of the fly ash by increasing oxidation and absorption (Zhao et al. 2017).

However, final arsenic content in the ashes may exceed regulatory limits used in agriculture, for example, or may even lead to the ashes being classified as toxic waste, which are not allowed for disposal in standard landfills. Clean-up of flue gases and filters also generates additional liquid effluents, which may contain non-negligible amounts of contaminants.

Table 13 Maximum levels ( $\mathrm{mg} \mathrm{kg}^{-1}$ dry weight) and maximum input $\left(\mathrm{g} \mathrm{ha}^{-1}\right)$ of arsenic, heavy metals and contaminants for sewage sludge used in agriculture

\begin{tabular}{|c|c|c|c|c|c|c|}
\hline \multirow[t]{2}{*}{ Compound } & \multicolumn{2}{|l|}{ France } & \multicolumn{2}{|l|}{ Europe } & \multicolumn{2}{|l|}{ USA } \\
\hline & Max level* & Max 10-year flux* & Max level & Max 10-year flux & Max level & Cumulative loading rate \\
\hline Total $\operatorname{arsenic}\left(\mathrm{As}_{\mathrm{t}}\right)$ & & & & & 41 & 41,000 \\
\hline \multicolumn{7}{|l|}{ Inorganic arsenic $\left(\mathrm{As}_{\mathrm{i}}\right)$} \\
\hline Cadmium (Cd) & 10 & 150 & $20-40$ & 1500 & 39 & 39,000 \\
\hline Chromium (Cr) & 1000 & 15,000 & - & - & & \\
\hline Mercury (Hg) & 10 & 150 & $16-25$ & 1000 & 17 & 17,000 \\
\hline Lead $(\mathrm{Pb})$ & 800 & 15,000 & $750-1200$ & 150,000 & 300 & 300,000 \\
\hline Nickel (Ni) & 200 & 3000 & $300-400$ & 30,000 & 420 & 420,000 \\
\hline PCB $* *$ & 0.8 & 12 & & & & \\
\hline Fluoranthene & 5 & 75 & & & & \\
\hline Benzo(b)fluoranthene & 2.5 & 40 & & & & \\
\hline Benzo(a)pyrene & 2 & 30 & & & & \\
\hline References & \multicolumn{2}{|c|}{17 August 1998 ruling } & \multicolumn{2}{|c|}{ Directive 86/278/EEC } & \multicolumn{2}{|c|}{40 CFR 503.13} \\
\hline
\end{tabular}

*General case: different limits apply for pastures and soils with $\mathrm{pH}<6$

**Main PCB: 28, 52, 101, 118, 138, 153 and 180 


\section{Conclusion}

Various members of the brown algal genus Sargassum spp. are reported as contaminated by heavy metals and, above all, (total) arsenic. Sargassum spp. valorization is a challenging economic opportunity, but industrial applications in food, in agriculture or for alginate extraction, especially from some Asian species, confirm its feasibility. Reactivity and organization are also a key to exploit such biomass, as most industrial processes require stable supply of well-preserved and sand-free algae, which is difficult to obtain from beach-cast biomass.

The high total arsenic content is an obstacle to food and feed valorization, even if Sargassum spp. consumption is traditional in Southeast Asia and other parts of the world, as food regulations drastically limit the arsenic content allowed. Some processes, reducing the arsenic concentration in Sargassum spp., have been developed in Asia, especially for S. fusiforme. Its raising consumption is a concern from food safety agencies worldwide. Transposition of these processes to other applications could be considered, especially for the extraction of value-added compounds (nutraceuticals, cosmetics, etc.), but may require further research to limit processing costs.

Sargassum valorization in agriculture, especially as compost and organic amendment, remains a challenge because of the volume involved and the need to reduce arsenic and sodium levels to acceptable levels, but incorporation in composts proves to be feasible, and more value-added applications, such as plant biostimulants, should be investigated further.

Lastly, energy production from Sargassum or from waste streams from its processing should be further explored. Whilst limited added value can be expected, this process could contribute to dealing with the volumes of seaweed collected, whilst concentrating the contaminants in a form that might be more easily handled. Similarly, the use of Sargassum spp. in biomaterials warrants higher academic interest to support industry developments. However, the fate of arsenic, i.e. metabolism, location of adsorption, relationship with transudate and so on, must be elucidated to support public authorities and decision-makers involved in Sargassum crisis governance. Moreover, arsenic transformation in industrial processes should be clarified further, at least to underpin regulatory compliance, at best for pre-treatment process optimization and waste management (liquid, gaseous and/or solid ones).

In some studies, organic micropollutant concentrations in Sargassum spp. also reach concerning levels for a marine matrix, considering that marine matrices classically exhibit low levels due to dilution. However, organic micropollutants are not routinely monitored. Studies are scarce and related to specific pollution contexts, as the Deepwater Horizon event. Organic micropollutant contents reported have thus to be regarded with caution. Data is lacking to determine whether Sargassum spp. present a higher risk of organic micropollutant contamination compared to other marine matrices, and whether this might impact their downstream uses.

Sargassum spp. are a promising matrix triggering renewed interest in response to recent Sargassum spp. blooms and the large volumes of biomass available. Promising valorization routes, especially in industrial fields, should be explored further with a focus on processes and their impact on contaminants.

Acknowledgements The authors wish to thank the ADEME, Martinique Agency, and especially Charlotte Gully and Clio Maridakis, for their financial, logistical and reflexive support, as well as Celia Northam for rereading and correcting the English version.

Funding This study received financial support from ADEME, Martinique Agency, and from ANSES during the preliminary work (No. 2016-CRD-09).

\section{References}

Abdallah AMA, Abdallah MA, Belgaty AI (2005) Contents of heavy metals in marine seaweeds from the Egyptian coast of the Red Sea. Chem Ecol 21:399-411

Abdel-Fattah AF, Hussein MMH, Salem HM (1974) Studies of the purification and some properties of sargassan, a sulphated heteropolysaccharides from Sargassum linifolium. Carbohydr Res 33:9-17

AFSSA (2009) Avis de l'Agence Française de Sécurité Sanitaire des Aliments relatif à la teneur maximale en arsenic inorganique recommandée pour les algues laminaires et aux modalités de consommation de ces algues compte tenu de leur teneur élevée en iode. Saisine 2007-SA-0007. Accessed 16 June 2020. In French

Aknin M, Dogbevi K, Samb A, Kornprobst J-M, Gaydou EM, Miralles J (1992) Fatty acid and sterol composition of eight brown algae from the Senegalese coast. Comp Biochem Physiol B 102:841-843

Al Mamun MA, Omori Y, Papry RI, Kosugi C, Miki O, Rahman IMM, Mashio AS, Maki T, Hasegawa H (2019) Bioaccumulation and biotransformation of arsenic by the brown macroalga Sargassum patens C. Agardh in seawater: effects of phosphate and iron ions. J Appl Phycol 31:2669-2685

Alahverdi M, Savabieasfahani M (2012) Seaweed and chlorophyll as biomarkers of metals in the Persian Gulf, Iran. Bull Environ Contam Toxicol 89:501-506

Ale MT, Meyer AS (2013) Fucoidans from brown seaweeds: an update on structures, extraction techniques and use of enzymes as tools for structural elucidation. RSC Adv 3:8131-8141

Al-Homaidan AA (2008) Accumulation of nickel by marine macroalgae from the Saudi coast of the Arabian Gulf. J Food Agric Envir 6:148 151

Al-Masri MS, Mamish S, Budier Y (2003) Radionuclides and trace metals in eastern Mediterranean Sea algae. J Environ Radioact 67: $157-168$

Almela C, Clemente MJ, Vélez D, Montoro R (2006) Total arsenic, inorganic arsenic, lead and cadmium contents in edible seaweed sold in Spain. Food Chem Toxicol 44:1901-1908

Al-Shwafi NA, Rushdi AI (2008) Heavy metal concentrations in marine green, brown, and red seaweeds from coastal waters of Yemen, the Gulf of Aden. Environ Geol 55:653-660 
Amado Filho GM, Andrade LR, Karez CS, Farina M, Pfeiffer WC (1999) Brown algae species as biomonitors of $\mathrm{Zn}$ and $\mathrm{Cd}$ at Sepetiba Bay, Rio de Janeiro, Brazil. Mar Environ Res 48:213-224

Amado Filho GM, Salgado LT, Rebelo MF, Rezende CE, Karez CS, Pfeiffer WC (2008) Heavy metals in benthic organisms from Todos os Santos Bay, Brazil. Braz J Biol 68:95-100

Anderson LWJ (2007) Control of invasive seaweeds. Bot Mar 50:418 437

Andersson M, Karumbunathan V, Zimmermann MB (2012) Global iodine status in 2011 and trends over the past decade. J Nutr 142:744 750

Andréfouët S, Payri C, Van Wynsberge S, Lauret O, Alefaio S, Preston G, Yamano H, Baudel S (2017) The timing and the scale of the proliferation of Sargassum polycystum in Funafuti Atoll, Tuvalu. J Appl Phycol 29:3097-3108

Angell AR, Mata L, de NR, Paul NA (2016) The protein content of seaweeds: a universal nitrogen-to-protein conversion factor of five. J Appl Phycol 28:511-524

ANSES (2011) Avis de l'Agence nationale de sécurité sanitaire de l'alimentation, de l'environnement et du travail relatif aux risques liés aux émissions gazeuses des algues vertes pour la santé des populations avoisinantes, des promeneurs et des travailleurs. https://www.anses.fr/fr/system/files/AIR2010sa0175Ra.pdf. Accessed 11 August 2020. In French

Aouissi M, Sellam LN, Boudouresque CF, Blanfuné A, Derbal F, Frihi H, Perret-Boudouresque M, Rebzani-Zahaf C, Verlaque M, Thibaut T (2018) Insights into the species diversity of the genus Sargassum (Phaeophyceae) in the Mediterranean Sea, with a focus on a previously unnoticed taxon from Algeria. Mediterr Mar Sci 19:48-57

Aponte de Otaola NE, Diaz-Piferrer M, Graham HD (1983) Seasonal variations and anatomical distribution of alginic acid in Sargassum spp. found along the coasts of Puerto Rico. J Agric Univ Puerto Rico $67: 464-475$

ASEAN (2017) ASEAN guidelines on limits of contaminants for Cosmetics v. 2.0. http://asean.org/wp-content/uploads/2012/05/ ASEAN-Guidelines-Limits-of-Contaminant-Cosmetics-.pdf. Accessed 16 June 2020

Athukorala Y, Lee K-W, Kim S-K, Jeon Y-J (2007) Anticoagulant activity of marine green and brown algae collected from Jeju Island in Korea. Bioresour Technol 98:1711-1716

Azam MS, Kwon M, Choi J, Kim H-R (2018) Sargaquinoic acid ameliorates hyperpigmentation through cAMP and ERK-mediated downregulation of MITF in $\alpha$-MSH-stimulated B16F10 cells. Biomed Pharmacother 104:582-589

Balboa EM, Conde E, Moure A, Falqué E, Domínguez H (2013) In vitro antioxidant properties of crude extracts and compounds from brown algae. Food Chem 138:1764-1785

Balboa EM, Soto ML, Nogueira DR, González-López N, Conde E, Moure A, Vinardell MP, Mitjans M, Domínguez H (2014) Potential of antioxidant extracts produced by aqueous processing of renewable resources for the formulation of cosmetics. Ind Crop Prod 58:104-110

Battacharyya D, Babgohari MZ, Rathor P, Prithiviraj B (2015) Seaweed extracts as biostimulants in horticulture. Sci Hortic 196:39-48

Belattmania Z, Chaouti A, Reani A, Machado M, Engelen AH, Serrão EÁ, Sabour B (2018a) Similar epiphytic macrofauna inhabiting the introduced Sargassum muticum and native fucoids on the Atlantic coast of Morocco. Cryptogam Algol 39:269-292

Belattmania Z, Chaouti A, Reani A, Engelen AH, Machado M, Serrão EA, Sabour B (2018b) The introduction of Sargassum muticum modifies epifaunal patterns in a Moroccan seagrass meadow. Mar Ecol 39:12507

Benson AA (1984) Phytoplankton solved the arsenate-phosphate problem, marine phytoplankton and productivity. In: Holm-Hansen $\mathrm{O}$, Bolis L, Gilles R (eds) Marine phytoplankton and productivity.
Lecture notes on coastal and estuarine studies, vol 8. Springer, Berlin, pp 55-59

Benson AA, Katayama M, Knowles FC (1988) Arsenate metabolism in aquatic plants. Appl Organomet Chem 2:349-352

Bertagnolli C, Espindola APDM, Kleinübing SJ, Tasic L, Da Silva MGC (2014) Sargassum filipendula alginate from Brazil: seasonal influence and characteristics. Carbohydr Polym 111:619-623

Berteau O, Mulloy B (2003) Sulfated fucans, fresh perspectives: structures, functions, and biological properties of sulfated fucans and an overview of enzymes active toward this class of polysaccharide. Glycobiology 3:29R-40R

Bertilsson S, Widenfalk A (2002) Photochemical degradation of PAHs in freshwaters and their impact on bacterial growth - influence of water chemistry. Hydrobiologia 469:23-32

BGA (1985) Mitteilungen des Bundesgesundheitsamtes: Technisch vermeidbare Gehalte an Schwermetallen in kosmetischen Erzeugnissen. Bundesgesundheitsblatt 28:216

Bird KT, Chynoweth DP, Jerger DE (1990) Effects of marine algal proximate composition on methane yields. J Appl Phycol 2:207-213

Biswas B, Fernandes AC, Kumar J, Muraleedharan UD, Bhaskar T (2018) Valorization of Sargassum tenerrimum: value addition using hydrothermal liquefaction. Fuel 222:394-401

Biswas B, Kumar A, Fernandes AC, Saini K, Negi S, Muraleedharan UD, Bhaskar T (2020) Solid base catalytic hydrothermal liquefaction of macroalgae: effects of process parameter on product yield and characterization. Bioresour Technol 307:123232

Borines MG, de LRL, McHenry MP (2011) Bioethanol production from farming non-food macroalgae in Pacific island nations: chemical constituents, bioethanol yields, and prospective species in the Philippines. Renew Sust En Rev 15:4432-4435

Borines MG, de Leon RL, Cuello JL (2013) Bioethanol production from the macroalgae Sargassum spp. Bioresour Technol 138:22-29

Briand X, Morand P (1997) Anaerobic digestion of Ulva sp. 1. Relationship between Ulva composition and methanisation. J Appl Phycol 9:511-524

Brito GB, de Souza TL, Bressy FC, Moura CWN, Korn MGA (2012) Levels and spatial distribution of trace elements in macroalgae species from the Todos os Santos Bay, Bahia, Brazil. Mar Pollut Bull 64:2238-2244

Budhiyanti SA, Raharjo S, Marseno DW, Lelana IYB (2012) Antioxidant activity of brown algae Sargassum species extract from the coastline of Java Island. Am J Agric Biol Sci 7:337-346

Buwono NR, Risjani Y, Arsad S (2018) Anti-inflammatory and analgesic activity from brown algae Sargassum polycystum. J Pharm Sci Res 10:2092-2096

BVL (2017) Technically avoidable heavy metal contents in cosmetic products. J Consum Prot Food Sci 12:51-53

Cabral JP (2003) Copper toxicity to five Parmelia lichens in vitro. Environ Exp Bot 49:237-250

Cao X, Ma L, Shiralipour A, Harris W (2010) Biomass reduction and arsenic transformation during composting of arsenic-rich hyperaccumulator Pteris vittata L. Environ Sci Pollut Res Int 17: 586-594

Carreras HA, Pignata ML (2007) Effects of the heavy metals $\mathrm{Cu}^{2+}, \mathrm{Ni}^{2+}$, $\mathrm{Pb}^{2+}$, and $\mathrm{Zn}^{2+}$ on some physiological parameters of the lichen Usnea amblyoclada. Ecotox Environ Safe 67:59-66

Carrillo S, Ríos VH, Calvo C, Carranco ME, Casas M, Pérez-Gil F (2012) n-3 fatty acid content in eggs laid by hens fed with marine algae and sardine oil and stored at different times and temperatures. J Appl Phycol 24:593-599

Casas-Valdez M, Hernández-Contreras H, Marín-Alvarez A, AguilaRamírez RN, Hernández-Guerrero CJ, Sánchez-Rodríguez I, Carrillo-Domínguez S (2006) The seaweed Sargassum (Sargassaceae) as tropical alternative for goats' feeding. Rev Biol Trop 54:83-92 
Cecchi F, Pavan P, Mata-Alvarez J (1996) Anaerobic co-digestion of sewage sludge: application to the macroalgae from the Venice lagoon. Resour Conserv Recycl 17:57-66

CFDA (2015) Inventory of existing cosmetic ingredients in China. http:// www.cirs-reach.com/Cosmetic_Inventory/China_IECIC Inventory_of_Existing_Cosmetic_Ingredients_in_China.html. Accessed 25 Jan 2020

Cha S-H, Ko S-C, Kim D, Jeon Y-J (2011) Screening of marine algae for potential tyrosinase inhibitor: those inhibitors reduced tyrosinase activity and melanin synthesis in zebrafish. J Dermatol 38:354-363

Chakraborty S, Owens G (2014) Metal distributions in seawater, sediment and marine benthic macroalgae from the South Australian coastline. Int J Environ Sci Technol 11:1259-1270

Chamidah A (2018) Prebiotic index evaluation of crude laminaran of Sargassum sp. using feces of Wistar rats. IOP Conf Ser: Earth Environ Sci 139:12043

Chapman VJ, Chapman DJ (1980) Seaweeds and their uses. Chapman \& Hall, London

Chen JP, Hong L, Wu SN, Wang L (2002) Elucidation of interactions between metal ions and $\mathrm{Ca}$-alginate based ion exchange resin by spectroscopic analysis and modeling simulation. Langmuir 18: 9413-9421

Chen B-J, Shi M-J, Cui S, Hao S-X, Hider RC, Zhou T (2016) Improved antioxidant and anti-tyrosinase activity of polysaccharide from Sargassum fusiforme by degradation. Int J Biol Macromol 92: 715-722

Chen L, Chen P, Liu J, Hu C, Yang S, He D, Yu P, Wu M, Zhang X (2018a) Sargassum fusiforme polysaccharide SFP-F2 activates the NF-KB signaling pathway via CD14/IKK and P38 axes in RAW264.7 cells. Mar Drugs 16:264

Chen H-L, Tan H-L, Yang J, Wei Y-Y, Hu T-J (2018b) Sargassum polysaccharide inhibits inflammatory response in PCV2 infectedRAW264.7 cells by regulating histone acetylation. Carbohydr Polym 200:633-640

Cherry P, O'Hara C, Magee PJ, McSorley EM, Allsopp PJ (2019) Risks and benefits of consuming edible seaweeds. Nutr Rev 77:307-329

Choi YJ, Lee SR, Oh J-W (2014) Effects of dietary fermented seaweed and seaweed fusiforme on growth performance, carcass parameters and immunoglobulin concentration in broiler chicks. Asian Australas J Anim Sci 27:862-870

Christensen BE, Indergaard M, Smidsrød O (1990) Polysaccharide research in Trondheim. Carbohydr Polym 13:239-255

Chung MK, Tsui MTK, Cheung KC, Tam NFY, Wong MH (2007) Removal of aqueous phenanthrene by brown seaweed Sargassum hemiphyllum: sorption-kinetic and equilibrium studies. Sep Purif Technol 54:355-362

Chynoweth DP, Owens JM, Legrand R (2001) Renewable methane from anaerobic digestion of biomass. Renew Energy 22(1-3):1-8

Circuncisão AR, Catarino MD, Cardoso SM, Silva AMS (2018) Minerals from macroalgae origin: health benefits and risks for consumers. Mar Drugs 16:400

Clancy TM (2015) Biogeochemical evaluation of disposal options for arsenic-bearing wastes generated during drinking water treatment. $\mathrm{PhD}$ thesis, University of Michigan

Cole AJ, Roberts DA, Garside AL, de NR, Paul NA (2016) Seaweed compost for agricultural crop production. J Appl Phycol 28:629642

Connan S, Delisle F, Deslandes E, Gall EA (2006) Intra-thallus phlorotannin content and antioxidant activity in Phaeophyceae of temperate waters. Bot Mar 49:39-46

Costa LS, Fidelis GP, Telles SCB, Dantas-Santos N, Camara BGR, Cordeiro SL, Costa SPMS, Almeida-Lima J, Melo-Silveira RF, Oliveira RM, Albuquerque RLI, Andrade VGP, Rocha HAO (2011) Antioxidant and antiproliferative activities of heterofucans from the seaweed Sargassum filipendula. Mar Drugs 9:952-966
Costa JC, Oliveira JV, Pereira MA, Alves MM, Abreu AA (2015) Biohythane production from marine macroalgae Sargassum sp. coupling dark fermentation and anaerobic digestion. Bioresour Technol 190:251-256

Craig P (2003) Organometallic compounds in the environment. John Willey \& Sons Ltd., Chichester

Craigie JS (2011) Seaweed extract stimuli in plant science and agriculture. J Appl Phycol 23:371-393

Cruz-Suárez LE, Tapia Salazar M, Nieto López MG, Ricque Marie D (2008) A review of the effects of macroalgae in shrimp feeds and in co-culture. In: Cruz Suárez LE, Ricque Marie D, Tapia Salazar M, Nieto López MG (eds) Avances en Nutrición Acuícola IX. Universidad Autónoma de Nuevo León, Mexico, pp 304-333

CSHPF (1990) Avis du 9 janvier 1990 du Conseil Supérieur d'Hygiène Publique de France (section de l'alimentation). Bulletin officiel du ministère chargé de la santé $n^{\circ} 90 / 45$ p. 103. (Demande d'autorisation d'algues en alimentation humaine) In French

Cullen WR, Reimer KJ (2016) Arsenic is everywhere. Cause for concern? Royal Society of Chemistry, Cambridge, UK

David AH, Wen XW, Mark AS, Nicholas SF (1999) Dual-labeling techniques for trace metal biogeochemical investigations in aquatic plankton communities. Aquat Microb Ecol 19:129-138

Davis TA, Volesky B, Vieira RHSF (2000) Sargassum seaweed as biosorbent for heavy metals. Water Res 34:4270-4278

Davis TA, Llanes F, Volesky B, Diaz-Pulido G, McCook L, Mucci A (2003a) 1H-NMR study of Na alginates extracted from Sargassum spp. in relation to metal biosorption. Appl Biochem Biotechnol 110: 75-90

Davis TA, Volesky B, Mucci A (2003b) A review of the biochemistry of heavy metal biosorption by brown algae. Water Res 37:4311-4330

Davis TA, Llanes F, Volesky B, Mucci A (2003c) Metal selectivity of Sargassum spp. and their alginates in relation to their $\alpha$-L-guluronic acid content and conformation. Environ Sci Technol 37:261-267

Davis TA, Ramirez M, Mucci A, Larsen B (2004) Extraction, isolation and cadmium binding of alginate from Sargassum spp. J Appl Phycol 16:275-284

Dawczynski C, Schäfer U, Leiterer M, Jahreis G (2007) Nutritional and toxicological importance of macro, trace, and ultra-trace elements in algae food products. J Agric Food Chem 55:10470-10475

Deniaud-Bouët E, Hardouin K, Potin P, Kloareg B, Hervé C (2017) A review about brown algal cell walls and fucose-containing sulfated polysaccharides: cell wall context, biomedical properties and key research challenges. Carbohydr Polym 175:395-408

Denton GRW, Burdon-Jones C (1986) Trace metals in algae from the Great Barrier Reef. Mar Pollut Bull 17:98-107

Devault DA, Massat F, Dupuy L, Lambourdière J, Ménez F, Maridakis C, Hervé V, Péné-Annette A, Trouillefou M, Dolique F, Lopez P-J (2019) Contamination des sargasses par la chlordécone: l'autre défi des échouages aux Antilles. $49^{\text {th }}$ Colloquium of the French Research Group about Pesticides, May 21-24, 2019, Montpellier

Devault DA, Dolique F, Trouillefou M, Massat F, Lopez P-J (2020) Sargassum contamination by arsenic and chlordecone: fate ashore and in compost. $30^{\text {th }}$ Colloquium of the Society of Environmental Toxicology and Chemistry Sci-con, May 3-7, 2020, Dublin

Di Filippo-Herrera DA, Hernández-Carmona G, Muñoz-Ochoa M, Arvizu-Higuera DL, Rodríguez-Montesinos YE (2018) Monthly variation in the chemical composition and biological activity of Sargassum horridum. Bot Mar 61:91-102

Diaz-Vazquez LM, Rojas-Perez A, Fuentes-Caraballo M, Robles IV, Jena U, Das KC (2015) Demineralization of Sargassum spp. macroalgae biomass: selective hydrothermal liquefaction process for bio-oil production. Front Energy Res 3:6

Dos Santos VCG, de Pádua A, Salvado A, Dragunski DC, Clausen DN, Teixeira Tarley CR, Caetano J (2011) Highly improved chromium (III) uptake capacity in modified sugarcane bagasse using different chemical treatments. Quim Nova 35:1606-1611 
Draget KI, Skjåk-Bræk G, Christensen BE, Gåserød O, Smidsrød O (1996) Swelling and partial solubilization of alginic acid gel beads in acidic buffer. Carbohydr Polym 29(3):209-215

Duncan EG, Maher WA, Foster SD, Krikowa F, Mikac KM (2014) The degradation of arsenoribosides from Ecklonia radiata tissues decomposed in natural and microbially manipulated microcosms. Environ Chem 11:289-300

Duncan EG, Maher WA, Foster SD (2015) The formation and fate of organoarsenic species in marine ecosystems: do existing experimental approaches appropriately simulate ecosystem complexity? Environ Chem 12:149-162

Edmonds JS (2000) Diastereoisomers of an "arsenomethionine"-based structure from Sargassum lacerifolium: the formation of the arsenic-carbon bond in arsenic-containing natural products. Bioorg Med Chem Lett 10:1105-1108

Eichenberger W (1993) Betaine lipids in lower plants. Distribution of DGTS, DGTA and phospholipids and the intracellular localization and site biosynthesis of DGTS. Plant Physiol Biochem 31:213-221

Ellamie AM, Fouda WA, Ibrahim WM, Ramadan G (2020) Dietary supplementation of brown seaweed (Sargassum latifolium) alleviates the environmental heat stress-induced toxicity in male Barki sheep (Ovis aries). J Therm Biol 89:102561

El-Said GF, El-Sikaily A (2013) Chemical composition of some seaweed from Mediterranean Sea coast, Egypt. Environ Monit Assess 185: 6089-6099

Ender E, Subirana MA, Raab A, Krupp EM, Schaumlöffel D, Feldmann J (2019) Why is NanoSIMS elemental imaging of arsenic in seaweed (Laminaria digitata) important for understanding of arsenic biochemistry in addition to speciation information? J Anal At Spectrom 34:2295-2302

Fan X, Xia J, Long J (2018a) The potential of nonliving Sargassum hemiphyllum as a biosorbent for nickel(II) removal-isotherm, kinetics, and thermodynamics analysis. Environ Progr Sustain Energy 38:S250-S259

Fan S, Yu G, Nie W, Jin J, Chen L, Chen X (2018b) Antitumor activity and underlying mechanism of Sargassum fusiforme polysaccharides in CNE-bearing mice. Int J Biol 112:516-522

Favero N, Frigo MG (2002) Biomonitoring of metal availability in the southern basin of the Lagoon of Venice (Italy) by means of macroalgae. Water Air Soil Pollut 140:231-246

Ferguson JF, Gavis J (1972) A review of the arsenic cycle in natural water. Water Res 6:1259-1274

Fernando IPS, Jayawardena TU, Sanjeewa KKA, Wang L, Jeon Y-J, Lee WW (2018) Anti-inflammatory potential of alginic acid from Sargassum horneri against urban aerosol-induced inflammatory responses in keratinocytes and macrophages. Ecotoxicol Environ Saf 160:24-31

Figueira MM, Volesky B, Ciminelli VST (1997) Assessment of interference in biosorption of a heavy metal. Biotechnol Bioeng 54:344 350

Figueira MM, Volesky B, Mathieu HJ (1999) Modeling of the protonmetal ion exchange in biosorption. Environ Sci Technol 33:1840

Flórez-Fernández N, Illera M, Sánchez M, Lodeiro P, Dolores Torres M, Elvira López-Mosquera M, Soto M, Sastre de Vicente M, Domínguez H (2020) Integral valorization of Sargassum muticum. Chem Eng J:125635

Foroutan R, Mohammadi R, Ramavandi B (2018) Treatment of chromium-laden aqueous solution using $\mathrm{CaCl}_{2}$-modified Sargassum oligocystum biomass: characteristics, equilibrium, kinetic, and thermodynamic studies. Korean J Chem Eng 35:234-245

Francesconi KA, Edmonds JS, Stick RV (1992) Arsenic compounds from the kidney of the giant clam Tridacna maxima: isolation and identification of an arsenic-containing nucleoside. J Chem Soc Perkin Trans 1:1349-1357

Fu X, Cao C, Ren B, Zhang B, Huang Q, Li C (2018) Structural characterization and in vitro fermentation of a novel polysaccharide from
Sargassum thunbergii and its impact on gut microbiota. Carbohydr Polym 183:230-239

Fujita H, Tao K, Shimizu T, Yokose M (2000) Method of treating sludge containing arsenic. United States Patent No. 6106726

García-Sartal C (2012) Bioavailability and speciation of arsenic in edible seaweed. Ph.D. thesis. University of Santiago de Compostella, Spain, p 298

Gellenbeck KW (2012) Utilization of algal materials for nutraceutical and cosmeceutical applications - what do manufacturers need to know? J Appl Phycol 24:309-313

Gellenbeck KW, Chapman DJ (1986) Feasibility of mariculture of the brown seaweed, Sargassum muticum (Phaeophyta): growth and culture conditions, alginic acid content and conversion to methane. In: Barclay WR, McIntosh (eds) Algal biomass technologies: an interdisciplinary perspective. J Cramer, Vaduz, pp 107-115

Gerstle RW, Albrinck DN (1982) Atmospheric emissions of metals from sewage sludge incineration. J Air Poll Control Assoc 32:1119-1123

Ghadiryanfar M, Rosentrater KA, Keyhani A, Omid M (2016) A review of macroalgae production, with potential applications in biofuels and bioenergy. Renew Sust En Rev 54:473-481

Graba-Landry A, Hoey AS, Matley JK, Sheppard-Brennand H, Poore AGB, Byrne M, Dworjanyn SA (2018) Ocean warming has greater and more consistent negative effects than ocean acidification on the growth and health of subtropical macroalgae. Mar Ecol Prog Ser 595:55-69

Gramatica P, Giani E, Papa E (2007) Statistical external validation and consensus modeling: a QSPR case study for $\mathrm{K}$ oc prediction. $\mathrm{J}$ Molec Graph Modell 25:755-766

Grinham A, Kvennefors C, Fisher PL, Gibbes B, Albert S (2014) Baseline arsenic levels in marine and terrestrial resources from a pristine environment: Isabel Island, Solomon Islands. Mar Pollut Bull 88:354-360

Guerra Dore CMP, Faustino Alves, M. G. das C, Pofírio Will LSE, Costa TG, Sabry DA, de Souza Rêgo LAR de, Accardo CM, Rocha HAO, Filgueira LGA, Leite EL (2013) A sulfated polysaccharide, fucans, isolated from brown algae Sargassum vulgare with anticoagulant, antithrombotic, antioxidant and anti-inflammatory effects. Carbohydr Polym 91:467-475

Habig C, Ryther JH (1983) Methane production from the anaerobic digestion of some marine macrophytes. Resour Conserv 8:271-279

Han C, Cao X, Yu J-J, Wang X-R, Shen Y (2009) Arsenic speciation in Sargassum fusiforme by microwave-assisted extraction and LCICP-MS. Chromatography 69:587-591

Han W, Clarke W, Pratt S (2014) Composting of waste algae: a review. Waste Manag 34:1148-1155

Hanaoka K, Yosida K, Tamano M, Kuroiwa T, Kaise T, Maeda S (2001) Arsenic in the prepared edible brown alga hijiki, Hizikia fusiforme. Appl Organomet Chem 15:561-565

Haraguchi K, Ito Y, Takagi M, Fujii Y, Harada KH, Koizumi A (2016) Levels, profiles and dietary sources of hydroxylated PCBs and hydroxylated and methoxylated PBDEs in Japanese women serum samples. Envir Intern 97:155-162

Harries D, Cook E, Donnan D, Mair J, Harrow S, Wilson J (2007) The establishment of the invasive alga Sargassum muticum on the west coast of Scotland: rapid northwards spread and identification of potential new areas for colonisation. Aquat Invasions 2:367-377

Health Canada (2012) Guidance on heavy metal impurities in cosmetics. https://www.canada.ca/en/health-canada/services/consumerproduct-safety/reports-publications/industry-professionals/ guidance-heavy-metal-impurities-cosmetics.html. Accessed 19 December 2019.

Heo SJ, Jeon YJ (2009) Protective effect of fucoxanthin isolated from Sargassum siliquastrum on UV-B induced cell damage. J Photochem Photobiol B 95:101-107

Heo SJ, Ko SC, Kang SM, Kang HS, Kim JP, Kim SH, Lee KW, Cho MG, Jeon YJ (2008) Cytoprotective effect of fucoxanthin isolated 
from brown algae Sargassum siliquastrum against $\mathrm{H}_{2} \mathrm{O}_{2}$-induced cell damage. Eur Food Res Technol 228:145-151

Heo SJ, Yoon WJ, Kim KN, Ahn GN, Kang SM, Kang DH, Affan A, Oh C, Jung WK, Jeon YJ (2010) Evaluation of anti-inflammatory effect of fucoxanthin isolated from brown algae in lipopolysaccharidestimulated RAW 264.7 macrophages. Food Chem Toxicol 48: 2045-2051

Herbreteau F, Coiffard LJM, Derrien A, DeRoeck-Holtzhauer Y (1997) The fatty acid composition of five species of macroalgae. Bot Mar 40:25-28

Ho YB (1988) Metal levels in three intertidal macroalgae in Hong Kong waters. Aquat Bot 29:367-372

Holdt SL, Kraan S (2011) Bioactive compounds in seaweed: functional food applications and legislation. J Appl Phycol 23:543-597

Hope AB, Walker NA (1975) The physiology of giant algal cells. Cambridge University Press, Cambridge

Horn SJ, Ostgaard K, Horn SJ, Østgaard K (2001) Alginate lyase activity and acidogenesis during fermentation of Laminaria hyperborea. $\mathrm{J}$ Appl Phycol 13:143-152

Horowitz A, Presley BJ (1977) Trace metal concentrations and partitioning in zooplankton, neuston, and benthos from the south Texas outer continental shelf. Arch Environ Contam Toxicol 5: 241-255

Hou X, Yan X (1998) Study on the concentration and seasonal variation of inorganic elements in 35 species of marine algae. Sci Total Environ 222:141-156

Huang CY, Kuo CH, Chen PW (2017) Compressional-puffing pretreatment enhances neuroprotective effects of fucoidans from the brown seaweed Sargassum hemiphyllum on 6-hydroxydopamine-induced apoptosis in SH-SY5Y cells. Molecules 23:78

Hwang E, Park SY, Sun ZW, Shin HS, Lee DG, Yi TH (2014) The protective effects of fucosterol against skin damage in UVBirradiated human dermal fibroblasts. Mar Biotechnol 16:361-370

Ichikawa S, Kamoshida M, K’i H, Hamano M, Maitani T, Kaise T (2006) Decrease of arsenic in edible brown algae Hijikia fusiforme by the cooking process. Appl Organomet Chem 20:585-590

Immanuel G, Sivagnanavelmurugan M, Marudhupandi T, Radhakrishnan S, Palavesam A (2012) The effect of fucoidan from brown seaweed Sargassum wightii on WSSV resistance and immune activity in shrimp Penaeus monodon (Fab). Fish Shellfish Immunol 32:551-564

Ismail MM, El Zokm GM, El-Sayed AAM (2017) Variation in biochemical constituents and master elements in common seaweeds from Alexandria Coast, Egypt, with special reference to their antioxidant activity and potential food uses: prospective equations. Environ Monit Assess 189:648

Iwashima M, Mori J, Ting X, Matsunaga T, Hayashi K, Shinoda D, Saito H, Sankawa U, Hayashi T (2005) Antioxidant and antiviral activities of plastoquinones from the brown alga Sargassum micracanthum, a new chromene derivative converted from the plastoquinones. Biol Pharm Bull 28:374-377

Jadeja RN, Tewari A (2007) Effect of soda ash industry effluent on bioaccumulation of metals by seaweeds of coastal region of Gujarat, India. J Hazard Mater 147:148-154

Jalali R, Ghafourian H, Asef Y, Davarpanah SJ, Sepehr S (2002) Removal and recovery of lead using nonliving biomass of marine algae. J Hazard Mater 92:253-262

James DE, Manley SL, Carter MC, North WJ (1987) Effects of PCBs and hydrazine on life processes in microscopic stages of selected brown seaweeds. Hydrobiologia 151-152:411-415

Janarthanan M, Senthil Kumar M (2018) The properties of bioactive substances obtained from seaweeds and their applications in textile industries. J Ind Text 48:361-401

Janasie C (2018) Seaweed, kelp, and other aquaculture products - legal issues with cultivation and production as food sources. American
Agricultural Law Association - 39th Annual Agricultural Law Symposium

Jard G, Marfaing H, Carrère H, Delgenes JP, Steyer JP, Dumas C (2013) French Brittany macroalgae screening: composition and methane potential for potential alternative sources of energy and products. Bioresour Technol 144:92-498

Jaswir I, Tawakalit Tope A-H, Raus RA, Ademola Monsur H, Ramli N (2014) Study on anti-bacterial potentials of some Malaysian brown seaweeds. Food Hydrocoll 42:275-279

Jayasankar R (1993) Seasonal variation in biochemical constituents of Sargassum wightii (Greville) with reference to yield in alginic acid content. Seaweed Res Util 16:13-16

Jayawardena TU, Asanka Sanjeewa KK, Shanura Fernando IP, Ryu BM, Kang M-C, Jee Y, Lee WW, Jeon Y-J (2018) Sargassum horneri (Turner) C. Agardh ethanol extract inhibits the fine dust inflammation response via activating Nrf2/HO-1 signaling in RAW 264.7 cells. BMC Complement Altern Med 18:249

Jeong SC, Jeong YT, Lee SM, Kim JH (2015) Immune-modulating activities of polysaccharides extracted from brown algae Hizikia fusiforme. Biosci Biotechnol Biochem 79:1362-1365

Ji D, You L, Ren Y, Wen L, Zheng G, Li C (2017) Protective effect of polysaccharides from Sargassum fusiforme against UVB-induced oxidative stress in $\mathrm{HaCaT}$ human keratinocytes. J Funct Foods 36: 332-340

Jin W, Zhang W, Liu G, Yao J, Shan T, Sun C, Zhang Q (2017) The structure-activity relationship between polysaccharides from Sargassum thunbergii and anti-tumor activity. Int J Biol Macromol 105:686-692

Jin W, Liu B, Li S, Chen J, Tang H, Jiang D, Zhang Q, Zhong W (2018) The structural features of the sulfated heteropolysaccharide (ST-1) from Sargassum thunbergii and its neuroprotective activities. Int J Biol Macromol 108:307-313

Josefsson M, Jansson K (2011) Invasive alien species fact sheet, sargassum muticum. Online database of the european network on invasive alien species. NOBANIS. https://www.nobanis.org. Accessed June 2020

Kadam SU, Tiwari BK, O'Donnell CP (2015) Extraction, structure and biofunctional activities of laminarin from brown algae. Int J Food Sci Technol 50:24-31

Karez CS, Magalhaes VF, Pfeiffer WC (1994) Trace metal accumulation by algae in Sepetiba Bay, Brazil. Environ Pollut 83:351-356

Karickhoff SW, Brown DS, Scott TA (1979) Sorption of hydrophobic pollutants on natural sediments. Water Res 13:241-248

Katayama M (2015) Pre-cooking of edible marine brown algae for reduction of arsenic contents. JFNS 3:84-87

Kaviarasan T, Gokul MS, Henciya S, Muthukumar K, Dahms H-U, James RA (2018) Trace metal inference on seaweeds in Wandoor Area, Southern Andaman Island. Bull Environ Contam Toxicol 100: 614-619

Keusgen M, Falk M, Walter JA, Glombitza K-W (1997) A phloroglucinol derivative from the brown alga Sargassum spinuligerum. Phytochemistry 46:341-345

Khan N, Seshadri B, Bolan N, Saint CP, Kirkham MB, Chowdhury S, Yamaguchi N, Lee DY, Li G, Kunhikrishnan A, Qi F, Karunanithi R, Qiu R, Zhu YG, Syu CH (2016) Root iron plaque on wetland plants as a dynamic pool of nutrients and contaminants. In: Sparks DL (ed) Advances in agronomy, vol 138. Academic, NY, pp 1-96

Khoo KM, Ting YP (2001) Biosorption of gold by immobilized fungal biomass. Biochem Eng J 8:51-59

Kim JA, Ahn BN, Kong CS, Kim SK (2012) Protective effect of chromene isolated from Sargassum horneri against UV-A-induced damage in skin dermal fibroblasts. Exp Dermatol 21:630-631

Kim JA, Ahn BN, Kong CS, Kim SK (2013a) The chromene sargachromanol $\mathrm{E}$ inhibits ultraviolet A-induced ageing of skin in human dermal fibroblasts. Br J Dermatol 168:968-976 
Kim SS, Ly HV, Kim J, Choi JH, Woo HC (2013b) Thermogravimetric characteristics and pyrolysis kinetics of alga Sagarssum sp. biomass. Bioresour Technol 139:242-248

Kim K, Kim S, Khosravi S, Rahimnejad S, Lee K (2014) Evaluation of Sargassum fusiforme and Ecklonia cava as dietary additives for olive flounder (Paralichthys olivaceus). Turk J Fish Aquat Sci 14: 321-330

Kim HJ, Park C, Kim GY, Park EK, Jeon YJ, Kim S, Hwang HJ, Choi YH (2018) Sargassum serratifolium attenuates RANKL-induced osteoclast differentiation and oxidative stress through inhibition of $\mathrm{NF}-\mathrm{kB}$ and activation of the Nrf2/HO-1 signaling pathway. Biosc Trends 12:257-265

Kodithuwakku H, Parakrama MGIS, Heenatigala PPM, Pahalawattaarachchi V (2017) A comparative laboratory trial on the effect of Sargassum wightii incorporated formulated feed on growth performance and immunity development of Asian sea bass Lates calcarifer (Bloch 1790): can it be an alternative to commercial feed? Sri Lanka J Aquat 22:99

Kratochvil D, Volesky B (1998) Biosorption of Cu from ferruginous wastewater by algal biomass. Water Res 32:2760-2768

Kumar S, Sahoo D, Levine I (2015) Assessment of nutritional value in a brown seaweed Sargassum wightii and their seasonal variations. Algal Res 9:117-125

Lahaye M (1991) Marine-algae as sources of fibers - determination of soluble and insoluble dietary fiber contents in some sea vegetables. $\mathrm{J}$ Sci Food Agric 54:587-594

Lahaye M, Kaeffer B (1997) Seaweed dietary fibres: structure, physicochemical and biological properties relevant to intestinal physiology. Sci Aliment 17:563-584

Larsen RK, Baker JE (2003) Source apportionment of polycyclic aromatic hydrocarbons in the urban atmosphere: a comparison of three methods. Environ Sci Technol 37:1873-1881

Latifah RN, Warganegara FM (2018) Production and characterization of the healthy brown rice milk with sodium alginate addition from brown algae Sargassum binderi as emulsifier. IOP Conference Series: Earth Environ Sci 139:012046

Le Lann K (2009) Etude de la biodiversité des Sargassaceae (Fucales, Phaeophyceae) en milieux tempéré et tropical: écologie, chimiotaxonomie et source de composés bioactifs. PhD thesis, Université de Bretagne Occidentale. 368 pp. In French

Leal-Acosta ML, Shumilin E, Mirlean N, Delgadillo-Hinojosa F, Sánchez-Rodríguez I (2013) The impact of marine shallow-water hydrothermal venting on arsenic and mercury accumulation by seaweed Sargassum sinicola in Concepcion Bay, Gulf of California. Environ Sci Process Impacts 15:470-477

Lee HS, Volesky B (1999) Interference of aluminum in copper biosorption by an algal biosorbent. Water Qual Res J Can 34:519 533

Lee P-T, Quan Tran HT, Huang H-T, Nan F-H, Lee M-C (2020) Sargassum horneri extracts stimulate innate immunity, enhance growth performance, and upregulate immune genes in the white shrimp Litopenaeus vannamei. Fish Shellfish Immun 102:276-285

Leong RC, Marzinelli EM, Low J, Bauman AG, Lim EWX, Lim CY, Steinberg PD, Guest JR (2018) Effect of coral-algal interactions on early life history processes in Pocillopora acuta in a highly disturbed coral reef system. Front Mar Sci 5:385

$\mathrm{Li} \mathrm{H}$ (2015) $\mathrm{Cu}, \mathrm{Zn}$ and As contamination of seaweed beside Shizuki and Kanayama metal mines in Japan. Intern J Geomate 9:1411-1417

Li D, Chen L, Yi X, Zhang X, Ye N (2010) Pyrolytic characteristics and kinetics of two brown algae and sodium alginate. Bioresour Technol 101:7131-7136

Li D, Chen L, Chen S, Zhang X, Chen F, Ye N (2012a) Comparative evaluation of the pyrolytic and kinetic characteristics of a macroalga (Sargassum thunbergii) and a freshwater plant (Potamogeton crispus). Fuel 96:185-191
Li D, Chen L, Xu D, Zhang X, Ye N, Chen F, Chen S (2012b) Preparation and characteristics of bio-oil from the marine brown alga Sargassum patens C. Agardh. Bioresour Technol 104:737-742

Li G, Guo Y, Zhao W (2017a) Efficient adsorption removal of tetracycline by layered carbon particles prepared from seaweed biomass. Environ Prog Sustain 36:59-65

Li Y, Fu X, Duan D, Liu X, Xu J, Gao X (2017b) Extraction and identification of phlorotannins from the brown alga, Sargassum fusiforme (Harvey) Setchell. Mar Drugs 15:49

Li J, Han K, Li S (2018a) Porous carbons from Sargassum muticum prepared by $\mathrm{H}_{3} \mathrm{PO}_{4}$ and $\mathrm{KOH}$ activation for supercapacitors. J Mater Sci Mater Electron 29:8480-8491

Li Y, Fu X, Duan D, Xu J, Gao X (2018b) Comparison study of bioactive substances and nutritional components of brown algae Sargassum fusiforme strains with different vesicle shapes. J Appl Phycol 30: 3271-3283

Li J, Zhu Y, Wang C, Wei W, Liu Z, Tian Y, Zong P, Qiao Y, Qin S (2020) Golden seaweed tides from beach inundations as a valuable sustainable fuel resource: fast pyrolysis characteristics, product distribution and pathway study on Sargassum horneri based on model compounds. Algal Res 48:101888

Liang J, Xia J, Long J (2017) Biosorption of methylene blue by nonliving biomass of the brown macroalga Sargassum hemiphyllum. Water Sci Technol 76:1574-1583

Lim S, Kwon M, Joung E-J, Shin T, Oh C-W, Choi JS, Kim H-R (2018) Meroterpenoid-rich fraction of the ethanolic extract from Sargassum serratifolium suppressed oxidative stress induced by tert-butyl hydroperoxide in HepG2 cells. Mar Drugs 16:374

Liu L, Heinrich M, Myers S, Dworjanyn SA (2012) Towards a better understanding of medicinal uses of the brown seaweed Sargassum in traditional Chinese medicine: a phytochemical and pharmacological review. J Ethnopharmacol 142:591-619

Lodewijcksz W, Claesz C (1609) Premier livre de l'histoire de la navigation aux indes orientales, par les Hollandois. Cornille Nicolas $106 \mathrm{pp}$

Lourenco SO, Barbarino E, De-Paula JC, da Pereira S, LO, Marquez UML (2002) Amino acid composition, protein content and calculation of nitrogen-to-protein conversion factors for 19 tropical seaweeds. Phycol Res 50:233-241

Lozano G, Hardisson A, Gutierez AJ, Lafuente MA (2003) Lead and cadmium levels in coastal benthic algae (seaweeds) of Tenerife, Canary Islands. Environ Int 28:627-631

Ma WCJ, Chung HY, Ang PO, Kim J-S (2005) Enhancement of bromophenol levels in aquacultured silver seabream (Sparus sarba). J Agric Food Chem 53:2133-2139

Madenjian CP, Schmidt LJ, Chernyak SM, Elliott RF, Desorcie TJ, Begnoche LJ, Hesselberg RJ (1999) Variation in net trophic transfer efficiencies among 21 PCB congeners. Environ Sci Technol 33: 3768-3773

Magura J, Moodley R, Jonnalagadda SB (2016) Chemical composition of selected seaweeds from the Indian Ocean, KwaZulu-Natal coast, South Africa. J Environ Sci Health B 51:525-533

Maher WA (1983) Inorganic arsenic in marine organisms. Mar Pollut Bull:308-310

Maher W, Foster S, Krikowa F (2009) Arsenic species in Australian temperate marine food chains. Mar Freshw Res 60:885-892

Mahmoud SH, Salama DM, El-Tanahy AMR, Abd El-Samad EH (2019) Utilization of seaweed (Sargassum vulgare) extract to enhance growth, yield and nutritional quality of red radish plants. Ann Agric Sci 64:167-175

Mairh OP, Ramavat BK, Tewari A, Oza RM, Joshi HV (1989) Seasonal variation, bioaccumulation and prevention of loss of iodine in seaweeds. Phytochem 28:3307-3310

Marín A, Casas-Valdez M, Carrillo S, Hernández H, Monroy A, Sanginés L, Pérez-Gil F (2009) The marine algae Sargassum spp. (Sargassaceae) as feed for sheep in tropical and subtropical regions. Rev Biol Trop 57:1271-1281 
Marinho-Soriano E, Fonseca PC, Carneiro MAA, Moreira WSC (2006) Seasonal variation in the chemical composition of two tropical seaweeds. Bioresour Technol 97:2402-2406

Marks LM, Reed DC, Holbrook SJ (2018) Life history traits of the invasive seaweed Sargassum horneri at Santa Catalina Island, California. Aquat Invasions 13:339-350

Marr L, Kirchstetter TW, Harley RA, Miguel AH, Sussane VH, Hammond KS (1999) Characterization of polycyclic aromatic hydrocarbons in motor vehicle fuels and exhaust emissions. Environ Sci Technol 33:3091-3099

Martial J-J, Tirolien J (2018) Les sargasses captent-elles la chlordécone quand elles s'échouent sur un littoral contaminé? NI_IT2 2018.5 pp. In French

McKennedy J, Sherlock O (2015) Anaerobic digestion of marine macroalgae: a review. Renew Sustain Rev 52:1781-1790

Meharg AA (2004) Arsenic in rice - understanding a new disaster for South-East Asia. Trends Plant Sci 9:415-417

Mestrot A, Xie W-Y, Xue X, Zhu Y-G (2013) Arsenic volatilization in model anaerobic biogas digesters. Appl Geochem 33:294-297

Miao L, Yan W, Zhong L, Xu W (2014) Effect of heavy metals (Cu, Pb, and As) on the ultrastructure of Sargassum pallidum in Daya Bay, China. Environ Monit Assess 186:87-95

Michel P (1985) Arsenic in marine environment: bibliographic summary. Rev Trav Inst Pêches Marit 49 (3 and 4):175-185. In French

Milledge JJ, Harvey PJ (2016) Golden tides: problem or golden opportunity? The valorisation of Sargassum from beach inundations. J Mar Sci Engin 4:60

Milledge JJ, Nielsen BV, Harvey PJ (2019) The inhibition of anaerobic digestion by model phenolic compounds representative of those from Sargassum muticum. J Appl Phycol 31:779-786

Mohamed SF (2005) Biomonitoring of heavy metals in some brown algal species in the Red Sea area (Saudi Arabia and Egypt). Arab Gulf J Scient Res 23:126-131

Mohammed A, Rivers A, Stuckey DC, Ward K (2020) Alginate extraction from Sargassum seaweed in the Caribbean region: optimization using response surface methodology. Carbohydr Polym 245:116419

Mohapatra D, Mishra D, Chaudhury GR, Das RP (2008) Removal of arsenic from arsenic rich sludge by volatilization using anaerobic microorganisms treated with cow dung. Soil Sediment Contam 17: 301-311

Moino BP, Costa CSD, Queiroz BGM, Landers R, da Silva MGC, Vieira MGA (2020) Reuse of the alginate extraction waste from Sargassum filipendula for $\mathrm{Ni}(\mathrm{II})$ biosorption. Chem Eng Commun 207:17-30

Montingelli ME, Tedesco S, Olabi AG (2015) Biogas production from algal biomass: a review. Renew Sust Energ Rev 43:961-972

Morand P, Briand X (1999) Anaerobic digestion of Ulva sp. 2. Study of Ulva degradation and methanisation of liquefaction juices. J Appl Phycol 11:165-177

Morand P, Briand X, Charlier RH (2006) Anaerobic digestion of Ulva sp. 3. Liquefaction juices extraction by pressing and a technicoeconomic budget. J Appl Phycol 18:741-755

Morillo E, Romero AS, Madrid L, Villaverde J, Maqueda C (2008) Characterization and sources of PAHs and potentially toxic metals in urban environments of Sevilla (Southern Spain). Water Air Soil Pollut 187:41-51

Murray LA, Raab A, Marr IL, Feldmann J (2003) Biotransformation of arsenate to arsenosugars by Chlorella vulgaris. Appl Organomet Chem 17:669-674

Naidu R, Smith E, Owens G, Bhattacharya P, Nadebaum P (2006) Managing arsenic in the environment: from soil to human health. CSIRO Publishing, Collingwood $664 \mathrm{pp}$

Naja G, Volesky B (2006) Multi-metal biosorption in a fixed-bed flowthrough column. Coll Surf A 281:194-201

Namvar F, Mohamad R, Baharara J, Zafar-Balanejad S, Fargahi F, Rahman HS (2013) Antioxidant, antiproliferative, and antiangiogenesis effects of polyphenol-rich seaweed (Sargassum muticum). Biomed Res Int 604787

Neff JM, Stout SA, Gunster DG (2005) Ecological risk assessment of polycyclic aromatic hydrocarbons in sediments: identifying sources and ecological hazard. Integr Environ Assess Manag 1:22-33

Negm NA, Abd El Wahed MG, Hassan ARA, Abou Kana MTH (2018) Feasibility of metal adsorption using brown algae and fungi: effect of biosorbents structure on adsorption isotherm and kinetics. J Mol Liq 264:292-305

Nisizawa K, Noda H, Kikuchi R, Watanabe T (1987) The main seaweed foods in Japan. Hydrobiologia 151/152:5-29

North WJ, James DE (1987) Use of Cystoseira and Sargassum embryonic sporophytes for testing toxicity effects. Hydrobiologia 151$152: 417-423$

Nzihou A, Stanmore B (2013) The fate of heavy metals during combustion and gasification of contaminated biomass-a brief review. J Hazard Mater 256-257:56-66

Okuku EO, Peter HK (2012) Choose of heavy metals pollution biomonitors: a critic of the method that uses sediments total metals concentration as the benchmark. Intern J Environ Res 6:313-322

Olabarria C, Arenas F, Fernández Á, Troncoso JS, Martínez B (2018) Physiological responses to variations in grazing and light conditions in native and invasive fucoids. Mar Environ Res 139:151-161

Oliveira JV, Alves MM, Costa JC (2015) Optimization of biogas production from Sargassum sp. using a design of experiments to assess the co-digestion with glycerol and waste frying oil. Bioresour Technol 175:480-485

Oyesiku OO, Egunyomi A (2014) Identification and chemical studies of pelagic masses of Sargassum natans (Linnaeus) Gaillon and $S$. fluitans (Borgessen) Borgesen (brown algae), found offshore in Ondo State, Nigeria. Afr J Biotechnol 13:1188-1193

Pan Y, Wernberg T, de Bettignies T, Holmer M, Li K, Wu J, Lin F, Yu Y, Xu J, Zhou C, Huang Z, Xiao X (2018) Screening of seaweeds in the East China Sea as potential bio-monitors of heavy metals. Environ Sci Pollut Res 25:16640-16651

Park C, Jeong JW, Lee DS, Yim MJ, Lee JM, Han MH, Kim S, Kim HS, Kim GY, Park EK, Jeon YJ, Cha HJ, Choi YH (2018) Sargassum serratifolium extract attenuates interleukin-1 $\beta$-induced oxidative stress and inflammatory response in chondrocytes by suppressing the activation of NF-kB, p38 MAPK, and PI3K/Akt. Int J Mol Sci 19:2308

Patra M, Bhowmik N, Bandopadhyay B, Sharma A (2004) Comparison of mercury, lead and arsenic with respect to genotoxic effects on plant systems and the development of genetic tolerance. Environ Exp Bot 52:199-223

Pereira L (2016) Edible seaweeds of the world. Taylor \& Francis, Boca Raton

Perez CMT, Pajares IG, Alcantara VA, Simbahan JF (2018) Bacterial laminarinase for application in ethanol production from brown algae Sargassum sp. using halotolerant yeast. Biofuel Res J 5:792-797

Pérez-Larrán P, Torres MD, Flórez-Fernández N, Balboa E, Moure A, Domínguez H (2019) Green technologies for cascade extraction of Sargassum muticum bioactives. J Appl Phycol 31:2481-2495

Pérez-López P, Balboa EM, González-García S, Dominguez H, Feijoo G, Moreira MT (2014) Comparative environmental assessment of valorization strategies of the invasive macroalgae Sargassum muticum. Bioresour Technol 161:137-148

Peu P, Sassi JF, Girault R, Picard S, Saint-Cast P, Béline F, Dabert P (2011) Sulphur fate and anaerobic biodegradation potential during co-digestion of seaweed biomass (Ulva sp.) with pig slurry. Bioresour Technol 102:10794-10802

Pham MA, Lee K-J, Lee B-J, Lim S-J, Kim S-S, Lee Y-D, Heo M-S, Lee K-W (2006) Effects of dietary Hizikia fusiformis on growth and immune responses in juvenile olive flounder (Paralichthys olivaceus). Asian Australas J Anim Sci 19:1769-1775 
Pichler T, Amend JP, Garey J, Hallock P, Hsia NP, Karlen DJ, MeyerDombard DR, McCloskey BJ, Price RE (2006) A natural laboratory to study arsenic geobiocomplexity. Eos, Trans AGU 87:221-225

Porse H, Rudolph B (2017) The seaweed hydrocolloid industry: 2016 updates, requirements, and outlook. J Appl Phycol 29:2187-2200

Powell KJ, Brown PL, Byrne R, Gajda T, Hefter G, Sjöberg S, Wanner H (2005) Chemical speciation of environmentally significant heavy metals with inorganic ligands part 1: The $\mathrm{Hg}^{2+}, \mathrm{Cl}^{-}, \mathrm{OH}^{-}, \mathrm{CO}_{3}{ }^{2-}$, $\mathrm{SO}_{4}{ }^{2-}$, and $\mathrm{PO}_{4}{ }^{3-}$ aqueous systems (IUPAC technical report). Pure Appl Chem 77:739-800

Powell KJ, Brown PL, Byrne RH, Gajda T, Hefter G, Leuz A-K, Sjöberg S, Wanner H (2009) Chemical speciation of environmentally significant metals with inorganic ligands. Part 3: the $\mathrm{Pb}^{2+}, \mathrm{OH}^{-}, \mathrm{Cl}^{-}$, $\mathrm{CO}_{3}{ }^{2-}, \mathrm{SO}_{4}{ }^{2-}$, and $\mathrm{PO}_{4}{ }^{3-}$ systems (IUPAC technical report). Pure Appl Chem 81:2425-2476

Powell KJ, Brown PL, Byrne RH, Gajda T, Hefter G, Leuz A-K, Sjöberg S, Wanner H (2011) Chemical speciation of environmentally significant metals with inorganic ligands. Part 4: the $\mathrm{Cd}^{2+}, \mathrm{OH}^{-}, \mathrm{Cl}^{-}$, $\mathrm{CO}_{3}{ }^{2-}, \mathrm{SO}_{4}{ }^{2-}$, and $\mathrm{PO}_{4}{ }^{3-}$ systems (IUPAC technical report). Pure Appl Chem 83:1163-1214

Preeprame S, Hayashi K, Lee JB, Sankawa U, Hayashi T (2001) A novel antivirally active fucan sulfate derived from an edible brown alga, Sargassum horneri. Chem Pharm Bull 49:484-485

Préfecture du Finistère (2014) Demande d'autorisation au titre de la protection de l'environnement. Enquête publique ${ }^{\circ}$ E14000204/35. http://pref29.alkante.com/sit_1_ALK/upload/actu/1301/rapport\% 20d\%20enquete\%20partie\%201.pdf. Accessed 11 August 2020

Prince JS, Daly EL (1981) The ecology of Sargassum pteropleuron Grunow (Phaeophyceae, Fucales) in the waters off South Florida. Phycologia 20:232-241

Punshon T, Jackson BP, Meharg AA, Warczack T, Scheckel K, Guerinot ML (2017) Understanding arsenic dynamics in agronomic systems to predict and prevent uptake by crop plants. Sci Total Environ 581582:209-220

Puranik PR, Modak JM, Paknikar KM (1999) A comparative study of the mass transfer kinetics of metal biosorption by microbial biomass. Hydrometallurgy 52:189-197

Pyle GG, Swanson SM, Lehmkuhl DM (2002) The influence of water hardness, $\mathrm{pH}$, and suspended solids on nickel toxicity to larval fathead minnows (Pimephales promelas). Water Air Soil Pollut 133: 215-226

Raber G, Francesconi KA, Irgolic KJ, Goessler W (2000) Determination of 'arsenosugars' in algae with anion-exchange chromatography and an inductively coupled plasma mass spectrometer as elementspecific detector. Fresenius J Anal Chem, 2000 367:181-188

Radulovich R, Umanzor S, Cabrera R (2013) Algas tropicales: Cultivo y uso como alimento, Universidad de Costa Rica, San José In Spanish

Ribera MA, Boudouresque CF (1995) Introduced marine plants, with special reference to macroalgae: mechanisms and impacts. Prog Phycol Res 11:187-268

Roberts DA, Johnston EL, Poore AGB (2008) Biomonitors and the assessment of ecological impacts: Distribution of herbivorous epifauna in contaminated macroalgal beds. Environ Pollut 156(2):489503

Robledo D, Pelegrin YF (1997) Chemical and mineral composition of six potentially edible seaweed species of Yucatan. Bot Mar 40:301-306

Rose M, Lewis J, Langford N, Baxter M, Origgi S, Barber M, MacBain H, Thomas K (2007) Arsenic in seaweed-forms, concentration and dietary exposure. Food Chem Toxicol 45:1263-1267

Rubín E, Rodríguez P, Herrero R, Sastre de Vicente M (2006) Biosorption of phenolic compounds by the brown alga Sargassum muticum. J Chem Technol Biotechnol 81:1093-1099

Rue EL, Bruland KW (1995) Complexation of iron(III) by natural organic ligands in the central North Pacific as determined by a new competitive ligand equilibration/adsorptive cathodic stripping voltammetric method. Mar Chem 50:117-138
Ruiz-Chancho MJ, Pichler T, Price RE (2010) in Arsenic in geosphere and human diseases, ed. J. Jiin-Shuh, J. Bundschuh and Bhattacharya, CRC, Boca Raton, pp. 226-228.

Saber M, Nakhshiniev B, Yoshikawa K (2016) A review of production and upgrading of algal bio-oil. Renew Sust Energ Rev 58:918-930

Saha BC, Racine FM (2011) Biotechnological production of mannitol and its applications. Appl Microbiol Biotechnol 89:879-891

Sánchez-Rodríguez I, Huerta-Diaz MA, Choumiline E, HolguínQuiñones O, Zertuche-González JA (2001) Elemental concentrations in different species of seaweeds from Loreto Bay, Baja California Sur, Mexico: implications for the geochemical control of metals in algal tissue. Environ Pollut 114:145-160

Sangha JS, Kelloway S, Critchley AT, Prithiviraj B (2014) Seaweeds (macroalgae) and their extracts as contributors of plant productivity and quality. In: Bourgougnon N (ed) Sea plants. Elsevier, Amsterdam, pp 189-219

Sanjeewa KKA, Fernando IPS, Kim S-Y, Kim H-S, Ahn G, Jee Y, Jeon Y-J (2018) In vitro and in vivo anti-inflammatory activities of high molecular weight sulfated polysaccharide; containing fucose separated from Sargassum horneri: short communication. Int J Biol Macromol 107:803-807

Sargasses \& Agriculture (2018) Utilisation déconseillée en épandage direct. http://www.guadeloupe.developpement-durable.gouv.fr/IMG/ pdf/sargasses_agriculture.pdf. Accessed 21 October 2020

Sato N (1988) Dual role of methionine in the biosynthesis of diacylglyceryltrimethylhomoserine in Chlamydomonas reinhardtii. Plant Physiol 86:931-934

Sawidis T, Brown MT, Zachariadis G, Stratis I (2001) Trace metal concentrations in marine macroalgae from different biotopes in the Aegean Sea. Environ Int 27:43-47

Schaffelke B, Hewitt CL (2007) Impacts of introduced seaweeds. Bot Mar 50:397-417

Schaffelke B, Smith JE, Hewitt CL (2006) Introduced macroalgae - a growing concern. J Appl Phycol 18:529-541

Schiener P, Black KD, Stanley MS, Green DH (2015) The seasonal variation in the chemical composition of the kelp species Laminaria digitata, Laminaria hyperborea, Saccharina latissima and Alaria esculenta. J Appl Phycol 27:363-373

Schiewer S, Volesky B (2000) in. In: Lovley D (ed) Environmental microbe-metal interactions. ASM, Washington, DC

Schiewer S, Wong MH (2000) Ionic strength effects in biosorption of metals by marine algae. Chemosphere 41:271-282

Schleder DD, Blank M, Peruch LGB, Vieira FN, Andreatta ER, Hayashi L (2017) Thermal resistance of Pacific white shrimp fed Sargassum filipendula: a MALDI-TOF mass spectrometry approach. Aquaculture 481:103-111

Seepersaud MA, Ramkissoon A, Seecharan S, Powder-George YL, Mohammed FK (2018) Environmental monitoring of heavy metals and polycyclic aromatic hydrocarbons (PAHs) in Sargassum filipendula and Sargassum vulgare along the eastern coastal waters of Trinidad and Tobago, West Indies. J Appl Phycol 30:2143-2154

Sembera JA (2013) Composting as an alternative management system for wild taro (Colocasia esculenta) and brown algae (Sargassum fluitans and Sargassum natans). MSc thesis, Texas State University, USA $119 \mathrm{pp}$

Sembera JA, Meier EJ, Waliczek TM (2018) Composting as an alternative management strategy for Sargassum drifts on coastlines. Horttechnology 28:80-84

Sharma SHS, Lyons G, McRoberts C, McCall D, Carmichael E, Andrews F, Swan R, McCormack R, Mellon R (2012) Biostimulant activity of brown seaweed species from Strangford Lough: compositional analyses of polysaccharides and bioassay of extracts using mung bean (Vigno mungo L.) and pak choi (Brassica rapa chinensis L.). J Appl Phycol 24:1081-1091

Sharma SHS, Fleming C, Selby C, Rao JR, Martin T (2014) Plant biostimulants: a review on the processing of macroalgae and use 
of extracts for crop management to reduce abiotic and biotic stresses. J Appl Phycol 26:465-490

Sheng PX, Ting Y-P, Chen JP, Hong L (2004) Sorption of lead, copper, cadmium, zinc, and nickel by marine algal biomass: characterization of biosorptive capacity and investigation of mechanisms. J Colloid Interface Sci 275:131-141

da Silva EB, Mussoline WA, Wilkie AC, Ma LQ (2019) Anaerobic digestion to reduce biomass and remove arsenic from Ashyperaccumulator Pteris vittata. Environ Pollut 250:23-28

Sjöberg S, Powell KJ, Brown PL, Byrne R, Gajda T, Hefter G, Leuz A-K, Wanner $\mathrm{H}$ (2013) Chemical speciation of environmentally significant metals with inorganic ligands. Part 5: the $\mathrm{Zn}^{2+}, \mathrm{OH}^{-}, \mathrm{Cl}^{-}, \mathrm{CO}_{3}{ }^{2-}$, $\mathrm{SO}_{4}{ }^{2-}$, and $\mathrm{PO}_{4}{ }^{3-}$ systems (IUPAC technical report). Pure Appl Chem 85:2249-2311

Smedley PL, Kinniburgh DG (2002) A review of the source, behaviour and distribution of arsenic in natural waters. Appl Geochem 17:517568

Smith KS, Balistrieri LS, Todd AS (2015) Using biotic ligand models to predict metal toxicity in mineralized systems. Appl Geochem 57: $55-72$

Sø HU (2011) Adsorption of arsenic and phosphate onto the surface of calcite as revealed by batch experiments and surface complexation modelling. PhD Thesis. Technical University of Denmark. 64 pp.

Soto M, Vázquez MA, de VA, Vilariño JM, Fernández G, de Vicente MES (2015) Methane potential and anaerobic treatment feasibility of Sargassum muticum. Bioresour Technol 189:53-61

Stark A, Abrajano T, Hellou J, Metcalf-Smith JL (2003) Molecular and isotopic characterization of polycyclic aromatic hydrocarbon distribution and sources at the international segment of the St. Lawrence River. Org Geochem 34:225-237

Stévant P, Duinker A, Fleurence J, Rustad T, Sandbakken I, Chapman A (2018) Biomass soaking treatments to reduce potentially undesirable compounds in the edible seaweeds sugar kelp (Saccharina latissima) and winged kelp (Alaria esculenta) and health risk estimation for human consumption. J Appl Phycol 30:2047-2060

Stirk WA, van Staden J (2006) Seaweed products as biostimulants in agriculture. In: Critchley AT, Ohno M (eds) World seaweed resources: an authoritative reference system. ETI BioInformatics, Amsterdam. pp 1-32

Stout SA, Litman E, Baker G, Franks JS (2018) Novel biological exposures following the Deepwater Horizon oil spill revealed by chemical fingerprinting. In: Stout SA, Wang Z (eds) Oil spill environmental forensics case studies. Elsevier, New York, pp 757-784

Sunarpi H, Ansyarif F, Eka Putri F, Azmiati S, Hidayatun Nufus N, Suparman WS, Prasedya ES (2019) Effect of Indonesian macroalgae based solid and liquid fertilizers on the growth and yield of rice (Oryza sativa). Asian J Plant Sci 18:15-20

Sung WC, Jer Wu C, Liang Pan C, Chin Lin Y (2018) Effect of different algal lees on physicochemical qualities of baked potato chips. J Mar Sci Tech-Taiwan 26:258-263

Széchy MTMD, Koutsoukos VDS, Barboza CADM (2017) Long-term decline of brown algal assemblages from southern Brazil under the influence of a nuclear power plant. Ecol Indic 80:258-267

Tabaraki R, Nateghi A (2016) Application of Taguchi L16 orthogonal array design to optimize hydrazine biosorption by Sargassum ilicifolium. Environ Prog Sustain 35:1450-1457

Taghavi S, Norouzi O, Tavasoli A, Di Maria F, Signoretto M, Menegazzo F, Di Michele A (2018) Catalytic conversion of Venice lagoon brown marine algae for producing hydrogen-rich gas and valuable biochemical using algal biochar and $\mathrm{Ni} / \mathrm{SBA}-15$ catalyst. Int $\mathrm{J}$ Hydrog Energy 43:19918-19929

Tanniou A, Vandanjon L, Incera M, Serrano Leon E, Husa V, Le Grand J, Nicolas J-L, Poupart N, Kervarec N, Engelen A, Walsh R, Guerard F, Bourgougnon N, Stiger-Pouvreau V (2013) Assessment of the spatial variability of phenolic contents and associated bioactivities in the invasive alga Sargassum muticum sampled along its European range from Norway to Portugal. J Appl Phycol 26:1215-1230

Taylor VF, Jackson BP (2016) Concentrations and speciation of arsenic in New England seaweed species harvested for food and agriculture. Chemosphere 163:6-13

Tensingh Baliah N, Lega Priyatharsini S, Celestin Sheeba P, Raja V (2017) Effect of seaweed liquid fertilizer of Sargassum wightii on the yield characters of Abelmoschus esculentus (L.) Moench. Intern J Adv Res Sci Engin Technol 4:4511-4518

Thresher RE (1999) Diversity, impacts and options for managing invasive marine species in Australian waters. Austral J Environ Manag 6:137-148

Thuy TTT, Ly BM, Van TTT, van Quang N, Tu HC, Zheng Y, SeguinDevaux C, Mi B, Ai U (2015) Anti-HIV activity of fucoidans from three brown seaweed species. Carbohydr Polym 115:122-128

Tobiszewski M, Namiesnik J (2012) PAH diagnostic ratios for the identification of pollution emission sources. Environ Pollut 162:110 119

Torres MR, Sousa APA, Silva Filho EAT, Melo DF, Feitosa JPA, de PRCM, Lima MGS (2007) Extraction and physicochemical characterization of Sargassum vulgare alginate from Brazil. Carbohydr Res 342:2067-2074

Torresi E, Polesel F, Bester K, Christensson M, Smets BF, Trapp S, Andersen HR, Plósz BG (2017) Diffusion and sorption of organic micropollutants in biofilms with varying thicknesses. Water Res 123:388-400

Tukaram Bai M, Venkateswarlu P (2018) Fixed bed and batch studies on biosorption of lead using Sargassum tenerrimum powder: characterization, kinetics and thermodynamics. Mater Today-Proc 5:18024 18037

Valentine JP, Magierowski RH, Johnson CR (2007) Mechanisms of invasion: establishment, spread and persistence of introduced seaweed populations. Bot Mar 50:351-360

Van Hal JW, Huijgen WJJ, López-Contreras AM (2014) Opportunities and challenges for seaweed in the biobased economy. Trends Biotechnol 32:231-233

Varzakas T, Labropoulos A, Anestis S (2016) Sweeteners: nutritional aspects, applications, and production technology. CRC, Boca Raton

Vergara Fernandez A, Vargas G, Alarcon N, Velasco A (2008) Evaluation of marine algae as a source of biogas in a two-stage anaerobic reactor system. Biomass Bioenergy 32:338-344

Vijayanand N, Ramya SS, Rathinavel S (2014) Potential of liquid extracts of Sargassum wightii on growth, biochemical and yield parameters of cluster bean plant. Asian Pac J Reprod 3:150-155

Vye SR, Dick JTA, Emmerson MC, O'Connor NE (2018) Cumulative effects of an invasive species and nutrient enrichment on rock pool communities. Mar Ecol Prog Ser 594:39-50

Wang S, Jiang XM, Han XX, Wang H (2008) Fusion characteristic study on seaweed biomass ash. Energy Fuel 22:2229-2235

Wang S, Wang Q, Jiang X, Han X, Ji H (2013) Compositional analysis of bio-oil derived from pyrolysis of seaweed. Energy Convers Manag 68:273-280

Wang CY, Wu TC, Hsieh SL, Tsai YH, Yeh CW, Huang CY (2015) Antioxidant activity and growth inhibition of human colon cancer cells by crude and purified fucoidan preparations extracted from Sargassum cristaefolium. J Food Drug Anal 23:766-777

Wang X, Shan T, Pang S (2018a) Phytoremediation potential of Saccharina japonica and Sargassum horneri (Phaeophyceae): biosorption study of strontium. Bull Environ Contam Toxicol 101:501-505

Wang L, Oh JY, Kim HS, Lee W, Cui Y, Lee HG, Kim YT, Ko JY, Jeon YJ (2018b) Protective effect of polysaccharides from Celluclastassisted extract of Hizikia fusiforme against hydrogen peroxideinduced oxidative stress in vitro in Vero cells and in vivo in zebrafish. Int J Biol Macromol 112:483-489

Wang L, Lee W, Oh JY, Cui YR, Ryu B, Jeon YJ (2018c) Protective effect of sulfated polysaccharides from Celluclast-assisted extract of 
Hizikia fusiforme against ultraviolet B-induced skin damage by regulating NF- $\mathrm{kB}$, AP-1, and MAPKs signaling pathways in vitro in human dermal fibroblasts. Mar Drugs 16:239

Weithmann N, Mlinar S, Hilbrig F, Bachmaf S, Arndt J, Planer-Friedrich B, Weig AR, Freitag R (2019) Arsenic metabolism in technical biogas plants: possible consequences for resident microbiota and downstream units. AMB Express 9:190

Wells ML, Potin P, Craigie JS, Raven JA, Merchant SS, Helliwell K, Smith A, Camire ME, Brawley SH (2017) Algae as nutritional and functional food sources: revisiting our understanding. J Appl Phycol 29:949-982

Wen ZS, Xiang XW, Jin HX, Guo XY, Liu LJ, Huang YN, OuYang XK, Qu YL (2016) Composition and anti-inflammatory effect of polysaccharides from Sargassum horneri in RAW264.7 macrophages. Int J Biol Macromol 88:403-413

Wijesekara I, Pangestuti R, Kim SK (2011) Biological activities and potential health benefits of sulfated polysaccharides derived from marine algae. Carbohydr Polym 84:14-21

Woignier T, Morell M, Morell O, Duffours L, Soler A (2011) Low water transport in fractal microstructure of tropical soils: application to chlordecone pesticide trapping. Ecohydrol Hydrobiol 11:121-127

Wong K, Cheung PC (2001) Influence of drying treatment on three Sargassum species. J Appl Phycol 13:43-50

Xia A, Cheng J, Song W, Su H, Ding L, Lin R, Lu H, Liu J, Zhou J, Cen $\mathrm{K}$ (2015) Fermentative hydrogen production using algal biomass as feedstock. Renew Sust Energ Rev 51:209-230

Xu Q, Qian Q, Quek A, Ai N, Zeng G, Wang J (2013) Hydrothermal carbonization of macroalgae and the effects of experimental parameters on the properties of hydrochars. ACS Sustain Chem Eng 1: 1092-1101

Yang J, Volesky B (1999) Cadmium biosorption rate in protonated Sargassum biomass. Environ Sci Technol 33:751-757

Ye H, Zhou C, Li W, Hu B, Wang X, Zeng X (2013) Structural elucidation of polysaccharide fractions from brown seaweed Sargassum pallidum. Carbohydr Polym 97:659-664

Ye Y, Ji D, You L, Zhou L, Zhao Z, Brennan C (2018) Structural properties and protective effect of Sargassum fusiforme polysaccharides against ultraviolet B radiation in hairless Kun Ming mice. J Funct Foods 43:8-16

Yoon WJ, Heo SJ, Han SC, Lee HJ, Kang GJ, Kang HK, Hyun JW, Koh YS, Yoo ES (2012) Anti-inflammatory effect of sargachromanol G isolated from Sargassum siliquastrum in RAW 264.7 cells. Arch Pharm Res 35:1421-1430

Yu M, Ji Y, Qi Z, Di C, Xin G, Wang B, Cao Y, Wang D (2017) Antitumor activity of sulfated polysaccharides from Sargassum fusiforme. Saudi Pharm J 25:464-468

Zamannejad N, Emadi H, Hafezieh M (2016) Effects of supplementation of algae (Sargassum ilicifolium) on growth, survival and body composition of rainbow trout Oncorhynchus mykiss. Iran J Fish Sci 1: 194-205

Zemke-White WL, Clements KD (2004) Relationship between long-term changes in algal community structure and herbivore diet at the three kings islands New Zealand. N Z J Mar Freshw Res 38(5):837-844

Zhao Y, Ren Q, Na Y (2017) Speciation transformation of arsenic during municipal sewage sludge incineration with cotton stalk as additive. Fuel 202:541-546

Zhao Y, Ren Q, Na Y (2018) Influence of operating parameters on arsenic transformation during municipal sewage sludge incineration with cotton stalk. Chemosphere 193:951-957

Zheng F, Chen L, Zhang P, Zhou J, Lu X, Tian W (2020) Carbohydrate polymers exhibit great potential as effective elicitors in organic agriculture: a review. Carbohydr Polym 230:115637

Zou HX, Pang QY, Zhang AQ, Lin LD, Li N, Yan XF (2015) Excess copper induced proteomic changes in the marine brown algae Sargassum fusiforme. Ecotoxicol Environ Saf 111:271-280

Zubia M, Payri C, Deslandes E (2008) Alginate, mannitol, phenolic compounds and biological activities of two range-extending brown algae, Sargassum mangarevense and Turbinaria ornata (Phaeophyta: Fucales), from Tahiti (French Polynesia). J Appl Phycol 20:10331043

Publisher's note Springer Nature remains neutral with regard to jurisdictional claims in published maps and institutional affiliations. 